\title{
Exercise based rehabilitation for heart failure (Review)
}

\author{
Rees K, Taylor RRS, Singh S, Coats AJS, Ebrahim S
}

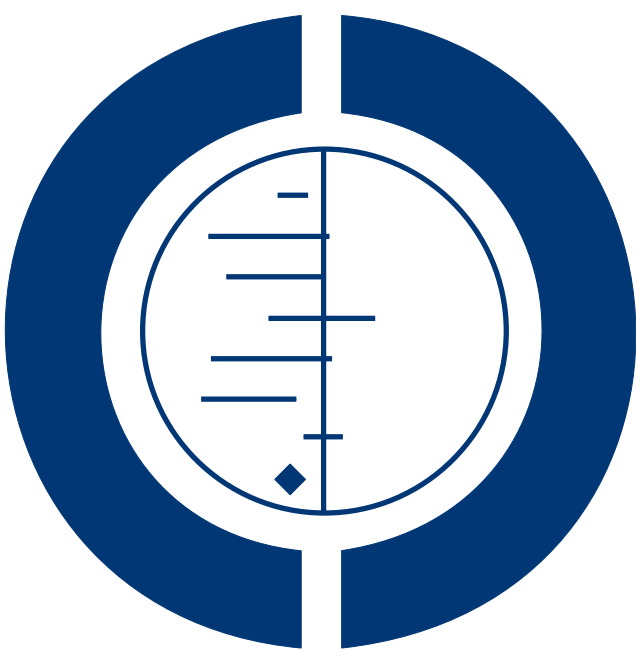

THE COCHRANE COLLABORATION $^{\circledR}$

This is a reprint of a Cochrane review, prepared and maintained by The Cochrane Collaboration and published in The Cochrane Library 2004, Issue 3

http://www.thecochranelibrary.com

\section{WILEY}


TABLE OF CONTENTS

HEADER . . . . . . . . . . . . . . . . . . . . . . . . . . . . . . . . . . . . . . . . 1

ABSTRACT . . . . . . . . . . . . . . . . . . . . . . . . . . . . . . . . . . . . . . . . . . . . . . . . . . 1

PLAIN LANGUAGE SUMMARY . . . . . . . . . . . . . . . . . . . . . . . . . . . . . . . . . . . . 2

BACKGROUND . . . . . . . . . . . . . . . . . . . . . . . . . . . . . . . . . . . . . .

OBJECTIVES . . . . . . . . . . . . . . . . . . . . . . . . . . . . . . . . . . . . . . . . . . . . .

METHODS . . . . . . . . . . . . . . . . . . . . . . . . . . . . . . . . . . . . . .

RESULTS . . . . . . . . . . . . . . . . . . . . . . . . . . . . . . . . . . . . . . . 5

DISCUSSION . . . . . . . . . . . . . . . . . . . . . . . . . . . . . . . . . . . . . 6

AUTHORS' CONCLUSIONS . . . . . . . . . . . . . . . . . . . . . . . . . . . . . . . . . . . . . . . . .

ACKNOWLEDGEMENTS . . . . . . . . . . . . . . . . . . . . . . . . . . . . . . . . . . 8

REFERENCES . . . . . . . . . . . . . . . . . . . . . . . . . . . . . . . . . . . . . . 8

CHARACTERISTICS OF STUDIES . . . . . . . . . . . . . . . . . . . . . . . . . . . . . . . .

DATA AND ANALYSES . . . . . . . . . . . . . . . . . . . . . . . . . . . . . . . . . . . . . . . . . . . . . . . . . .

Analysis 1.1. Comparison 1 All exercise interventions versus usual care, Outcome 1 Cardiac mortality. . . . . . . $\quad 26$

Analysis 1.2. Comparison 1 All exercise interventions versus usual care, Outcome 2 Non-fatal Myocardial Infarction. 27

Analysis 1.3. Comparison 1 All exercise interventions versus usual care, Outcome 3 Hospital readmission for Heart

Failure. . . . . . . . . . . . . . . . . . . . . . . . . . . . . . . . . . . . . 28

Analysis 1.4. Comparison 1 All exercise interventions versus usual care, Outcome 4 Deaths not associated with training but reported reasons for loss to follow-up. $\quad$. . . . . . . . . . . . . . . . . . . . . . . . . . . . . $\quad 29$

Analysis 1.5. Comparison 1 All exercise interventions versus usual care, Outcome $5 \mathrm{VO} 2 \mathrm{max}(\mathrm{ml} / \mathrm{kg} / \mathrm{min}) . \quad$. $\quad . \quad 30$

Analysis 1.6. Comparison 1 All exercise interventions versus usual care, Outcome 6 Exercise duration (mins). . . . . 31

Analysis 1.7. Comparison 1 All exercise interventions versus usual care, Outcome 7 Maximum work capacity (Watts). 32

Analysis 1.8. Comparison 1 All exercise interventions versus usual care, Outcome 8 Distance on 6 minute walk (meters). 33

Analysis 2.1. Comparison 2 Subgroup analyses, Outcome 1 VO2 $\max (\mathrm{ml} / \mathrm{kg} / \mathrm{min})$. . . . . . . . . . . . . . . . . 34

WHAT'S NEW . . . . . . . . . . . . . . . . . . . . . . . . . . . . . . . . . . . . . . 39

HISTORY . . . . . . . . . . . . . . . . . . . . . . . . . . . . . . . . . . . . . . . . . .

CONTRIBUTIONS OF AUTHORS . . . . . . . . . . . . . . . . . . . . . . . . . . . . . . . . . . . . . . . . .

DECLARATIONS OF INTEREST . . . . . . . . . . . . . . . . . . . . . . . . . . . . . . . . . . . . 39

SOURCES OF SUPPORT . . . . . . . . . . . . . . . . . . . . . . . . . . . . . . . . . . . . . 40

NOTES . . . . . . . . . . . . . . . . . . . . . . . . . . . . . . . . . . . . . . . . . 40

INDEX TERMS . . . . . . . . . . . . . . . . . . . . . . . . . . . . . . . . . . . . 40

Exercise based rehabilitation for heart failure (Review)

Copyright @ 2009 The Cochrane Collaboration. Published by John Wiley \& Sons, Ltd. 


\title{
[Intervention Review]
}

\section{Exercise based rehabilitation for heart failure}

\author{
Karen Rees ${ }^{1}$, Rod RS Taylor ${ }^{2}$, Sally Singh ${ }^{3}$, Andrew JS Coats ${ }^{4}$, Shah Ebrahim ${ }^{5}$ \\ ${ }^{1}$ Department of Social Medicine, Universiry of Bristol, Bristol, UK. ${ }^{2}$ PenTAG, Peninsula Medical School, Exeter, UK. ${ }^{3}$ Head of \\ Cardiac \& Pulmonary Rehabilitation,, Glenfield Hospital, Leicester, UK. ${ }^{4}$ University of Sydney, Sydney, Australia. ${ }^{5}$ Department of \\ Epidemiology \& Population Health, London School of Hygiene \& Tropical Medicine, London, UK \\ Contact address: Karen Rees, Department of Social Medicine, Universiry of Bristol, Whiteladies Road, Bristol, BS3 1AZ, UK. \\ rees_karen@yahoo.co.uk.
}

Editorial group: Cochrane Heart Group.

Publication status and date: Edited (no change to conclusions), published in Issue 1, 2009.

Review content assessed as up-to-date: 17 May 2004.

Citation: Rees K, Taylor RRS, Singh S, Coats AJS, Ebrahim S. Exercise based rehabilitation for heart failure. Cochrane Database of Systematic Reviews 2004, Issue 3. Art. No.: CD003331. DOI: 10.1002/14651858.CD003331.pub2.

Copyright (C) 2009 The Cochrane Collaboration. Published by John Wiley \& Sons, Ltd.

\begin{abstract}
A B S T R A C T
Background

The prevalence of chronic heart failure is increasing, and increases with increasing age. Major symptoms include breathlessness and restricted activities of daily living due to reduced functional capacity, which in turn affects quality of life. Exercise training has been shown to be effective in patients with coronary heart disease and has been proposed as an intervention to improve exercise tolerance in patients with heart failure.
\end{abstract}

\section{Objectives}

To determine the effectiveness of exercise based interventions compared with usual medical care on the mortality, morbidity, exercise capacity and health related quality of life, of patients with heart failure.

\section{Search strategy}

We searched the Cochrane Controlled Trials Register (The Cochrane Library Issue 2, 2001), MEDLINE (2000 to March 2001), EMBASE (1998 to March 2001), CINAHL (1984 to March 2001) and reference lists of articles. We also sought advice from experts.

\section{Selection criteria}

RCTs of exercise based interventions. The comparison group was usual medical care as defined by the study, or placebo. Adults of all ages with chronic heart failure. Only those studies with criteria for diagnosis of heart failure (based on clinical findings or objective indices) have been included.

\section{Data collection and analysis}

Studies were selected, and data were abstracted, independently by two reviewers. Authors were contacted where possible to obtain missing information.

\section{Main results}

Twenty-nine studies met the inclusion criteria, with 1126 patients randomised. The majority of studies included both patients with primary and secondary heart failure, NYHA class II or III. Only one study specifically examined the effect of exercise training on mortality and morbidity. Exercise training significantly increased $\mathrm{VO}_{2}$ max by (WMD random effects model) $2.16 \mathrm{ml} / \mathrm{kg} / \mathrm{min}(95 \%$ CI 2.82 to 1.49 ), exercise duration increased by 2.38 minutes (95\% CI 2.85 to 1.9 ), work capacity by 15.1 Watts (95\% CI 17.7 to

Exercise based rehabilitation for heart failure (Review)

Copyright $\odot 2009$ The Cochrane Collaboration. Published by John Wiley \& Sons, Ltd. 
12.6) and distance on the six minute walk by 40.9 metres (95\% CI 64.7 to 17.1$)$. Improvements in $\mathrm{VO}_{2}$ max were greater for training programmes of greater intensity and duration. HRQoL improved in the seven of nine trials that measured this outcome.

\section{Authors' conclusions}

Exercise training improves exercise capacity and quality of life in patients mild to moderate heart failure in the short term. One study found beneficial effects of exercise on cardiac mortality and hospital readmissions over 3 years of follow-up, the remaining included studies did not aim to measure clinical outcomes and were of short duration. The findings of the review are based on small-scale trials in patients who are unrepresentative of the total population of patients with heart failure. Other groups (more severe patients, the elderly, women) may also benefit. Large-scale pragmatic trials of exercise training of longer duration, recruiting a wider spectrum of patients are needed to address these issues.

\section{PLAIN LANGUAGESUMMARY}

\section{Exercise training improves exercise tolerance and quality of life in people with mild to moderate heart failure}

People with heart failure experience breathlessness and restricted activities of daily living because of their restricted heart capacity. This can reduce their amount of exercise, which can further reduce fitness, making their symptoms worse. The review found short-term trials of exercise training in people with mild to moderate heart failure only, which do not represent most of the people who have heart failure. The kinds of exercise programs varied greatly, but most included aerobic exercise rather than resistance training (such as working with weights). Exercise improved people's fitness and quality of life, without causing harm.

\section{B A C K G R O U N D}

The prevalence and incidence of chronic heart failure $(\mathrm{CHF})$ is steadily increasing with approximately 550,000 new cases annually in the United States (AHA). Whilst improved management of hypertension has reduced this condition as an aetiological factor in the development of heart failure, the increased survival rate from myocardial infarction has lead to a subsequent increase in the number of cases of chronic heart failure (Kostis 1997), as has increasing longevity in developed countries. In the developing world the occurrence of heart failure can often be attributed to valvular heart disease and nutritional cardiac disease (Lip 2000). Estimates of the prevalence of heart failure in Europe range from 0.4 to $2 \%$ in middle aged adults (Cowie 1997), but over 65 years of age the prevalence of CHF is in the region of 6 to $10 \%$. (Kannel 1991). Hospital admission rates for heart failure are rising in all industrialised countries, particularly among the elderly (McMurray 2000).

Patients with heart failure present with a variety of symptoms most of which are often non specific (Watson 2000). The most frequently presenting symptom is exertional breathlessness. Additional important symptoms may be fatigue and lethargy, in addition to swelling of the feet and ankles. Symptoms and functional exercise capacity are used to classify the severity of heart failure (using the New York Heart Association (NYHA) classification) and judge the response to treatment. Whilst the classification of severity is based upon symptoms, the diagnosis is secured with objective measures. The European Task Force report (CHF Taskforce 2001) proposes that the definition of heart failure should rely on two criteria: symptoms of heart failure at rest or during exercise (typically breathlessness and fatigue) and objective evidence of cardiac dysfunction at rest. Where the diagnosis is in doubt, a response to treatment directed towards heart failure may also be used in addition to the above criteria. However, like many chronic diseases there is a poor correlation between symptoms and the degree of cardiac impairment, and also between symptoms and disease prognosis ( Hülsmann 2002; Opasich 2001; van den Brock 1992).

Coupled with the pathological changes of heart failure and associated symptoms is a reduction in exercise tolerance due to impaired skeletal muscle function. Muscle function depends upon perfusion, muscle mass, fibre composition and energy metabolism - alteration of any of these will influence physical performance. Muscle performance can be defined as either strength or endurance and both can be reduced in chronic heart failure. For heart failure there is reduced capillary fibre ratio, reduced peripheral blood flow and an alteration in mitochondrial density, leading to a reduced oxidative capacity of the peripheral muscle (Drexler 1992; Mancini 1992; Sullivan 1989). Inactivity contributes to these changes. Decreased exercise capacity restricts activities of daily living, this in 
turn influences an individual's independence and quality of life.

The management of chronic heart failure is characterised by a combination of drugs and lifestyle changes. Drug therapy aims to control symptoms by controlling fluid balance and blocking neurohormonal activation. Lifestyle management is important in chronic heart failure and includes diet and exercise. Decreased exercise capacity is the main factor restricting daily activity for this patient group. Patients become trapped in a vicious circle of inactivity and decreasing functional capacity. Historically patients with heart failure were advised to avoid exertion for fear of worsening cardiac function due to myocardial stress. In the late 1970s and early 1980s it was reported that exercise training was safe in patients with impaired ventricular function. These studies reported a significant improvement in work capacity after training (Conn 1982; Lee 1979). In 1990 Coats and colleagues demonstrated a beneficial effect of exercise training on exercise tolerance, peak oxygen consumption and symptoms in a cross over trial of patients with heart failure, and concluded that rest as the mainstay of treatment for chronic heart failure should no longer be accepted (Coats 1990). This has been confirmed in a number of trials subsequently (e.g. Keteyian 1996; Kiilavuori 1996, ). More recently studies have focused on the central and peripheral physiological changes after precisely prescribed exercise regimens. The positive effects of exercise training are thought to occur mainly peripherally in skeletal muscle. These include reduced lactate production (delayed onset of anaerobic metabolism), improved aerobic capacity, reduced sympathetic drive and increased vagal tone (Belardinelli 1992; Coats 1992; Hambrecht 1995; Tyni-Lenne/Gordon 96). Ventilatory parameters also improve. Changes in peak oxygen consumption are consistently documented as are improved anaerobic threshold and decreases in the ventilatory equivalent for carbon dioxide (Tyni-Lenne 2001; Wielenga 1999 CHANGE). Some central cardio-vascular changes have been reported such as improved myocardial perfusion (Belardinelli 1999), improved cardiac output at sub-maximal work rates (Coats 1992), associated reduction in peak heart rates (Keteyian 1996) and improved peripheral blood flow (Dziekan 1998; Sullivan 1988).

The effectiveness of exercise based rehabilitation in patients with coronary heart disease (CHD) has been demonstrated in two early meta-analyses (Oldridge 1988; O'Connor 1989), and in an updated recent Cochrane systematic review (Jolliffe 2001). These systematic reviews specifically excluded patients with heart failure. Exercise based rehabilitation significantly reduces all cause and cardiac mortality, cholesterol and cigarette smoking in patients with CHD (Jolliffe 2001). The provision of cardiac rehabilitation for patients with $\mathrm{CHD}$ in the $\mathrm{UK}$ is required by recent policy $(\mathrm{Na}-$ tional Service Framework for Coronary Heart disease - Standard 12, DOH 2000). It is suggested that cardiac rehabilitation should also be considered as an option for patients with heart failure who may potentially benefit (Standard 11, DOH 2000). Currently, patients with heart failure are underrepresented in cardiac rehabili- tation programmes (NHS 1998).

The current review in a series on cardiac rehabilitation (Jolliffe 2001; Rees 2004) will concentrate on exercise based interventions for heart failure. The effectiveness of exercise based rehabilitation for patients with heart failure has been examined in a recent qualitative overview where the authors found beneficial effects on physical performance in 27 of 31 studies identified, on mortality in 1 of 31 studies, and of quality of life in 1 of 16 studies (Lloyd-Williams 2002). Whilst this review was comprehensive in its search strategy in that many data sources were searched, it did exclude non-English language publications, it included non randomised and before and after studies (only 22 of 31 studies were randomised controlled trials), and made no attempt to pool data statistically from those trials which were identified. Thus no estimate of effect size for exercise interventions for CHF patients was obtained for any outcome examined. Furthermore, several randomised controlled trials have been published which were not included in the above review.

\section{O B JE C T I VES}

To determine the effectiveness of exercise based interventions compared with usual medical care on the mortality, morbidity, exercise capacity and health related quality of life, of patients with heart failure. A secondary objective was to examine any adverse events associated with exercise in these patients.

\section{METHOD S}

\section{Criteria for considering studies for this review}

\section{Types of studies}

Randomised controlled trials either a parallel group or cross-over design.

\section{Types of participants}

All adults with chronic heart failure. Only those studies with criteria for diagnosis of heart failure (based on clinical findings or objective indices) have been included. Where possible we have distinguished between patients with primary heart failure (dilated cardiomyopathy - DCM), and those with heart failure secondary to coronary heart disease (CHD). Studies including patients who have previously been offered cardiac rehabilitation for either myocardial infarction or heart failure have been excluded. 


\section{Types of interventions}

Exercise based interventions, either alone or as a component of comprehensive cardiac rehabilitation (defined as programmes including also other components such as health education and psychological interventions, in addition to exercise interventions). The comparison group was usual medical care as defined by the study, or an "attention placebo".

\section{Types of outcome measures}

(1) All cause mortality;

(2) Morbidity - non-fatal myocardial infarction, revascularisation;

(3) Hospital admissions/re-hospitalisation;

(4) Exercise capacity;

(5) Physical activity levels;

(6) Validated measures of health related quality of life (HRQoL).

\section{Search methods for identification of studies}

We searched the Cochrane Controlled Trials Register (The Cochrane Library Issue 2, 2001) using the strategy outlined below. This was updated by searching MEDLINE (2000 to March 2001) on Ovid using a standard RCT filter (Dickersin 1994) and EMBASE (1998 to March 2001) using an EMBASE RCT filter (Lefebvre 1996) and searching CINAHL (1984 to March 2001). In addition, we searched reference lists of articles and sought expert advice. No language restrictions were applied.

CCTR Search Strategy

1. HEART-FAILURE-CONGESTIVE*:ME

2. (HEART and FAILURE)

3. (CARDIAC and FAILURE)

4. ((\#1 or \#2) or \#3)

5. REHABILITATION*:ME

6. EXERCISE*:ME

7. EXERCISE-THERAPY*:ME

8. SPORTS*:ME

9. PHYSICAL-EDUCATION-AND-TRAINING* ${ }^{*}$ ME

10. EXERTION*:ME

11. REHABILITAT*

12. (PHYSICAL* near FIT)

13. (PHYSICAL* near FITNESS)

14. (PHYSICAL near TRAIN*)

15. (PHYSICAL* near ACTIVIT*)

16. (TRAIN* near STRENGTH*)

17. (TRAIN* near AEROBIC*)

18. (AEROBIC* near EXERCISE*)

19. KINESIOTHERAP*

20. (EXERCISE* near TRAIN*)

21. $((()((()((()((\# 5$ or $\# 6)$ or $\# 7)$ or \#8) or \#9) or \#10) or \#11) or $\# 12)$ or \#13) or \#14) or \#15) or \#16) or \#17) or \#18) or \#19) or $\# 20)$

22. (\#4 and \#21)

\section{Data collection and analysis}

\section{Study selection}

From the searches, the title and abstract of each paper was reviewed by one reviewer $(\mathrm{KR})$ and potentially relevant references retrieved. Following this initial screening, two reviewers (KR, RT) independently selected trials to be included in this review using predetermined inclusion criteria. In all cases disagreements about any study inclusions were resolved by consensus. The general agreement for two raters over all categories (study included, excluded or pending) was assessed by Cohen's kappa (weighted). Observed agreement was $88.3 \%$, expected agreement $54 \%$, Kappa $=0.75$ (95\% confidence interval $=0.57$ to 0.93$)$. The quality of trials was assessed in terms of concealment of allocation, losses to follow up, and blind assessment of outcomes. Quality was also assessed by using the Jadad Scale (Jadad 1996).

\section{Data extraction}

Study outcome data were extracted by one reviewer (KR) and chief investigators were contacted to provide additional relevant information. Data extraction was checked by a second reviewer (RT) in a random sample of 10 studies.

\section{Data analysis}

Dichotomous outcomes were expressed as odds ratios, and 95\% confidence intervals (CI) were calculated for each study. For continuous variables net changes were compared (i.e. control group minus intervention group differences) and a weighted mean difference (WMD) or standardised mean difference (SMD) and 95\% $\mathrm{CI}$ have been calculated for each study. Where standard deviation differences were not reported in the source papers, allowance has been made for within patient correlation from baseline to follow up measurements by using the correlation coefficient between the two (Cochrane Heart Group; Follmann 1992).

For cross-over trials, data from the first arm only has been included. Where data for the two arms is combined then this has been accepted only if the authors state there are no carryover effects, or there is evidence of washout.

For each outcome, a test of heterogeneity was carried out. In the situation of no heterogeneity, fixed effects meta-analysis was used. If substantial heterogeneity $(\mathrm{p}<0.1)$ was detected, the reviewers looked for possible explanations (e.g. participants and intervention) for this. If the heterogeneity could not be explained, the reviewers considered the following options: not to aggregate the studies at all, or use a random effects model with appropriate cautious interpretation. Where a random effects model has been used this is indicated in parentheses.

Stratified analyses and meta-regression were used to examine the effect of intensity of the intervention, age, duration of follow up and trial quality on the outcome $\mathrm{VO}_{2}$ max, the outcome most frequently reported in the included studies. These subgroups were defined in advance. Sensitivity analysis was carried out to examine the effect of excluding the few studies which did not include an aerobic training component.

Exercise based rehabilitation for heart failure (Review)

Copyright $\odot 2009$ The Cochrane Collaboration. Published by John Wiley \& Sons, Ltd. 


\section{RE S U L T S}

\section{Description of studies}

See: Characteristics of included studies; Characteristics of excluded studies.

From the searching, 1162 studies were found, the title and abstracts of these were screened and 79 went forward for formal inclusion or exclusion. Thirty three separate trials met the inclusion criteria. Of these, 4 were later excluded; 3 because of insufficient data despite contacting the authors to obtain information, and one because of overlap in the participants recruited in another included study. Data from the remaining 29 studies with 1126 patients randomised were used in the analyses. Of these 29 trials, 23 evaluate an aerobic intervention and 6 report resistance training of peripheral muscle groups. Twenty three of the trials are parallel group design, the remaining 6 are cross over trials. The majority of trials include both patients with primary (dilated cardiomyopathy) and secondary (ischemic heart disease) heart failure, with only 4 trials reporting these patient groups separately. All patients included met the New York Heart Association (NYHA) criteria for symptoms (class II or III) and all had a left ventricular ejection fraction $(\mathrm{LVEF})<40 \%$. The mean age of participants across the included studies ranged from 51 to 77 years. Most studies recruited predominantly male patients with the exception of two studies that recruited only women (Pu 2001; Tyni-Lenne 1997). Mean follow up was 20 (SD 14) weeks (range 4 to 60 weeks) for exercise variables and quality of life. One study reported clinical data at 3.3 years of follow-up (Belardinelli 1999).

Details of the studies included in the review are shown in the table 'Characteristics of included studies'. Reasons for exclusion are presented in the table 'Characteristics of excluded studies'.

\section{Risk of bias in included studies}

The methodological quality of the included studies are presented in Table 01 . The methodological quality of trials in terms of the method of randomisation, allocation concealment, blinding of outcome assessors and losses to follow up, is as was reported in the papers. For the majority of studies, both the method of randomisation, and the method of allocation concealment were unclear. Most of the trials were short term studies and so therefore the loss to follow up was low, with the exception of five trials where this was greater than $20 \%$. The median Jadad score for the 34 trials was 2 (interquartile range 2 to 3 , range 1 to 4 ), out of a possible score of 5 (Jadad 1996). The Jadad score has been used as an overall indicator of trial quality in the stratified analyses to examine its impact on outcome (see results section).

\section{Effects of interventions}

\section{Clinical events}

Only one study with long term follow-up aimed to examine the effect of exercise on mortality and morbidity (Belardinelli 1999). This study showed that cardiac mortality was statistically significantly reduced with the exercise intervention over 3.3 years of follow-up (99 patients randomised, odds ratio 0.32 (95\% CI 0.13, $0.8)$ ), as were hospital readmissions for heart failure (odds ratio $0.28(95 \%$ CI $0.09,0.85))$. There was no statistically significant effect of the intervention on non-fatal myocardial infarction (odds ratio $0.48(95 \% \mathrm{CI} 0.04,5.47))$.

Several studies report deaths as dropouts during the study period, which the authors state were unrelated to the intervention (Gottlieb 1999; Hambrecht 1995; Hambrecht 1998; Hambrecht 2000; Owen 2000; Ponikowski 1997; Teo 1995 EXERT; Wielenga 1999 CHANGE). Nonetheless, if we pool this data for all cause mortality there is no significant difference between the intervention and control groups (odds ratio 1.12 (95\% CI 0.58 to 2.15$)$ ). The follow-up period for these trials ranged from 16 to 52 weeks. One study reported a non-fatal MI in the control group (Ponikowski 1997), none of the studies report other clinical events.

\section{Adverse events}

Whilst not a primary objective of the review, all studies were examined for reports of any adverse events during exercise training. Adverse events were those as defined by the authors, and/or clinical events (including deaths, myocardial infarction, arrhythmias) reported to be associated with exercise training. The majority of studies state that there were no adverse events associated with the intervention (17 of 29 studies), although these studies were not designed to examine safety, nor did they state in their objectives that they would do so. Only one trial reported complications associated with training, but these were confined to the most severe patients with ejection fractions below 30\% (Jette 1991).

\section{Exercise variables}

For all variables concerned with exercise capacity, an increase in value from baseline to follow-up indicates improvement with the exercise intervention. For this reason, the sign of the mean change in these variables for both the intervention and control groups has been changed for the pooled analysis so the direction of effect is in the appropriate direction on the Metaview plots.

$\mathrm{VO}_{2}$ max was measured in 24 studies (848 participants randomised) and improved markedly with exercise training by 2.16 $\mathrm{ml} / \mathrm{kg} / \mathrm{min}$ (WMD random effects model, 95\% CI 2.82 to 1.49 ). Similar significant improvements were seen for exercise duration measured in 15 studies (510 participants randomised) which increased by 2.38 minutes (WMD 95\% CI 2.85 to 1.92 ), and maximum work capacity measured in six studies (219 participants randomised) which increased by 15.1 Watts (WMD 95\% CI 17.7 to 12.6) in the training group. Distance on the six minute walk was measured in eight studies (282 participants randomised) which increased by 40.9 metres (WMD random effects model 95\% CI 64.7 to 17.1$)$. Heterogeneity between studies for this outcome is

Exercise based rehabilitation for heart failure (Review) 
due to one trial (Teo 1995 EXERT) that showed no effect of intervention, whilst the remaining seven showed large positive effects. This trial measured outcomes over the short (3 months) and longer term (12 months) and results were similar for both time periods.

\section{Subgroup analyses}

Marked heterogeneity was seen for the outcome $\mathrm{VO}_{2}$ max (chi square 61.27, $\mathrm{p}<0.00001$ ), and to explore this further we carried out a number of prespecified subgroup analyses. The cut-off points used for each explanatory variable were the median values for the studies reporting this outcome.

The variables thought to have an impact on heterogeneity between studies included

- the intensity of the intervention ("Dose" calculated as the number of weeks multiplied by the number of sessions per week, multiplied by the duration of sessions in hours);

- duration of the intervention;

- trial quality assessed by the Jadad score (determined from what was reported in the papers);

- duration of follow-up and

- mean age.

The "dose" of the intervention varied from 3 to 112 units (mean 40.3 SD 30.7), and the duration of the intervention varied from 3 to 52 weeks (mean 16 SD 11.5) across the studies.

Interventions of greater intensity had a larger effect on the improvements seen in $\mathrm{VO}_{2}$ max but the $95 \%$ CI's overlapped with lower doses suggesting that the difference between the two was not statistically significant (Dose $>30$ units WMD, random effects model 2.78 (95\% CI 3.88 to 1.69)), Dose < 30 units WMD 1.64 (95\% CI 2.2 to 1.1). Slightly larger effects on $\mathrm{VO}_{2}$ max were seen with studies of poorer methodological quality (Jadad score 2 and below), but this was not statistically significant. The improvement in $\mathrm{VO}_{2}$ max was greater in patients aged less than 55 years WMD 2.95 (95\% CI 4.25 to 1.64$)$ versus greater than 55 years WMD 1.77 (95\% CI 2.5 to 1.03), but again this does not reach statistical significance. Age is reported in all studies as an aggregate measure and thus comparison between these two age groups may be misleading as individual patient data are not available to examine effects across the whole age range. The effect size increased with increasing duration of follow-up, but this is a marker also for the duration of the intervention since most studies were short term with follow-up assessment at or shortly following the end of the intervention.

\section{Meta regression}

Heterogeneity for the outcome $\mathrm{VO}_{2}$ max was also examined with meta-regression. Covariates defined a priori included trial quality, dose of intervention, duration of intervention and length of follow-up. In univariate analyses, the Jadad score had no effect on the level of $\mathrm{VO}_{2}$ max achieved at the end of exercise training. Statistically significant associations were seen with dose of intervention, duration of intervention and duration of follow-up. In multivariate analyses both the dose of the intervention and the duration of follow-up contributed to the heterogeneity of $\mathrm{VO}_{2}$ max, where the weighted mean difference (WMD) for $\mathrm{VO}_{2}$ max is multiplied by a factor of 1.01 per unit increase in dose (coefficient $\log$ WMD $0.013795 \%$ CI 0.0019 to $0.025 \mathrm{p}=0.023$ ), and the weighted mean difference for $\mathrm{VO}_{2}$ max is multiplied by a factor of 1.03 per week increase in follow-up duration (coefficient log WMD 0.0302 95\% CI 0.013, $0.046 \mathrm{p}<0.001$ ). Thus the level of $\mathrm{VO}_{2}$ max at the end of exercise training increases with increasing dose of the intervention, and increasing follow-up period. As noted above, since most studies were short term studies, the follow-up period is a marker for exercise duration, which is also included in the estimate of dose.

\section{Sensitivity analyses}

The majority of studies include an aerobic exercise component. To determine the impact of aerobic exercise alone, sensitivity analyses were carried out excluding studies which focused exclusively on resistance training. This had no significant effect on the pooled analysis for the outcomes $\mathrm{VO}_{2}$ max or distance on the 6 minute walk.

\section{Health related quality of life}

The number of different scales used to assess HRQoL, and the different intervention groups (both aerobic and resistance training), as well as the relatively few trials that reported this as an outcome, meant that a pooled analysis was inappropriate. Data has been presented qualitatively in Table 02 . Nine of 29 trials reported HRQoL as an outcome. Seven out of nine studies found improvements in HRQoL in the intervention group compared to control. Five studies used the disease specific measure the Minnesota Living with Heart Failure questionnaire (Belardinelli 1999; Parnell 2002; Ponikowski 1997; Teo 1995 EXERT; Tyni-Lenne 2001) where significant improvements were seen for $4 / 5$ studies over the short term. Two of these 5 studies measured quality of life over the longer term of 12 months, one showed improvement was maintained over the long term (Belardinelli 1999), the other showed no difference between intervention and control groups, as for the shorter term assessment (Teo 1995 EXERT). Other scales used included the MOS Short Form (SF) 36, CHF questionnaire, Sickness Impact Profile (SIP) and Nottingham Health Profile (NHP) parts 1 and 2 .

\section{DISCUSSION}

This is the most comprehensive systematic review to date to examine the effectiveness of exercise training for heart failure. However, the trials identified for inclusion were mostly small and of relatively poor methodological quality, recruiting mostly men, and patients with stable chronic heart failure. Patients with severe disease and co-morbidities were often excluded. The findings therefore are confined to this particular group of patients and may not be generalisable to all patients with heart failure. 
Highly statistically significant improvements in exercise capacity were found as assessed by maximum oxygen uptake, exercise duration, distance on the 6 minute walk and physical work capacity. These improvements in intermediate outcomes confirm previous findings (Lloyd-Williams 2002). As most trials are of relatively short duration, it is unclear whether these improvements are sustained. Indeed, conflicting results were found for the two largest trials monitoring the effects of exercise training over 12 months where sustained improvement in functional capacity was found in one trial (Belardinelli 1999), and no effect of exercise training was found in the other (Teo 1995 EXERT).

One of our principal objectives was to determine the effect of exercise training on clinical outcomes. Only one trial with a long follow-up period examined the effect of exercise training on mortality and morbidity, where favorable outcomes were seen for cardiac mortality and hospital readmissions (Belardinelli 1999). The authors of this trial state that the patients who died had a higher resting heart rate, end-diastolic diameter and wall thickening score index, and lower systolic blood pressure and $\mathrm{VO}_{2}$ max at peak exercise than those patients who survived. Other studies did report clinical events as reasons for loss to follow-up, but the majority of these ( $7 / 8$ trials) were short term studies. Pooling this data for the 8 of 29 trials reporting all cause mortality showed no evidence of effect of exercise training on this outcome. Further longer term trials are needed to examine the effect of exercise training on clinical outcomes. Several trials are currently underway and we await the results with interest. The Exercise Intervention Strategies in Heart Failure Trial (EXIST) is a multicentre trial designed to examine the effect of exercise training on morbidity and mortality in heart failure patients (NRR ongoing trial 1). The trial was due to be completed in December 2002. Another trial, due to complete in January 2004 looks specifically at elderly patients with heart failure and whether long term provision of exercise training can improve mortality and morbidity (NRR ongoing trial 2).

Whilst it was not our primary aim to examine adverse events, it is noteworthy that only one of 29 trials reported complications associated with training, and in the most severe patients (Jette 1991). As most of the trials are conducted in patients with stable chronic heart failure with NYHA functional class II or III, perhaps this is not unexpected. Concerns about safety have historically been the reason for exclusion of heart failure patients from exercise training and cardiac rehabilitation programmes. Today, it is now generally accepted that exercise training is safe in patients with stable heart failure, but that there is as yet no trial evidence to recommend exercise training in unstable heart failure or those with NYHA class IV (CHF Guidelines 2001). We were unable to examine the effects of exercise training separately for those patients with dilated cardiomyopathy and those with heart failure secondary to coronary heart disease as most trials recruited a mix of these patients, the majority being those in the latter group. Similarly we were unable to examine the effects of gender or age on outcome.
Lack of research evidence in these groups may result in exclusion of women and the elderly from training programmes.

Relatively few trials examined health related quality of life. Of those that used validated scales to assess this, many different instruments were used over different time periods which meant that pooling data statistically was inappropriate. Most of the studies that measured this outcome ( 7 of 9 studies) showed beneficial effects of exercise training. As for the exercise variables above, the 2 trials which measured quality of life over the long term (12 months) had conflicting results (Belardinelli 1999; Teo 1995 EXERT). More large scale trials of longer duration are needed to resolve these discrepancies. The publication of the two longer term ongoing trials cited above (NRR ongoing trial 1, NRR ongoing trial 2) will add to the existing evidence and may help resolve these issues.

The exercise intervention varied in mode, intensity and duration between studies. The current guidelines for exercise training in heart failure acknowledge the benefits of aerobic training but that the precise protocol is yet to be established and should be individually tailored to baseline clinical and functional status. Relatively little attention has been paid to resistance training, and it is not generally recommended until further data are available (CHF Guidelines 2001). Most of the studies included in this review examined aerobic training. Exclusion of the few studies which focused exclusively on resistance training had no effect on functional outcomes. The outcome $\mathrm{VO}_{2}$ max was most frequently reported and showed large heterogeneity between studies. To try to explain this and examine the impact of different levels of exercise on $\mathrm{VO}_{2}$ max, we performed metaregression. The dose of the intervention (the product of exercise duration, number of sessions and duration of training period) explained much of the variation, with improvements in $\mathrm{VO}_{2}$ max seen for increasing "doses" of exercise training. This finding is important and with the advent of longer term studies, the longer term effects of different training periods can be established.

\section{A U THORS' CONCLUSIONS}

\section{Implications for practice}

This review shows that exercise training improves exercise capacity and HRQoL in patients with NYHA functional status class II or III heart failure. However, further work is necessary to inform clinical guideline development. At present exercise training is only recommended in those patients with stable heart failure and NYHA functional class II or III, and only aerobic exercise training is recommended in a supervised hospital based setting, each protocol being tailored to individual needs. Whilst each patient must be treated as an individual, some broad protocols informed by research would help in clinical practice. Due to lack of research there is little evidence of benefit in certain groups (more severe 
patients, elderly people, women) who may then subsequently be omitted from programmes. The trial evidence to date is unlikely to represent the majority of patients with heart failure.

\section{Implications for research}

The findings are based on small trials in patients who are unrepresentative of the total population of patients with heart failure. The effectiveness of exercise training on functional capacity and quality of life is clear in the short term but is unknown in the longer term. Large, long-term pragmatic trials of exercise training are needed to determine the effectiveness of exercise training on morbidity, quality of life, and mortality. The value of continued exercise training for maintenance of benefit also requires evaluation.

\section{ACKNOW LEDGEMENTS}

We would like to acknowledge the following authors for providing us with additional data, A Maiorana, A Gordon.

We would like to acknowledge Dr Andrea Conti and Dr Jan Melichar for translations.

\section{R E F E R E N C E S}

\section{References to studies included in this review}

\section{Belardinelli 1992 \{published data only\}}

Belardinelli R, Scocco V, Mazzanti M, et al.Effects of aerobic training in patients with moderate chronic heart failure. Giornale italiano di cardiologia 1992;22(8):919-30.

Belardinelli 1995 \{published data only\}

Belardinelli R, Georgiou D, Cianci G, Berman N, Ginzton L, Purcaro A. Exercise training improves left ventricular diastolic filling in patients with dilated cardiomyopathy. Clinical and prognostic implications. Circulation 1995;91 (11):2775-84

Belardinelli 1999 \{published data only\} Belardinelli R, Georgiou D, Cianci G, Purcaro A. Randomized, controlled trial of long-term moderate exercise training in chronic heart failure: effects on functional capacity, quality of life, and clinical outcome. Circulation 1999;99(9):1173-82.

Cider 1997 \{published data only\}

Cider A, Tygesson H, Hedberg M, Seligman L, Wennerblom B, Sunnerhagen KS. Peripheral muscle training in patients with clinical signs of heart failure. Scandinavian Journal of Rehabilitation Medicine 1997;29(2):121-7.

Coats 1990 \{published data only\}

Coats A, Adamopoulos S. A cross-over comparison of outpatient physical training versus rest in the treatment of moderate to severe heart failure [abstract]. Clinical Science 1989;77(Suppl 21):19P.

Coats AJ, Adamopoulos S, Meyer TE, Conway J, Sleight P. Effects of physical training in chronic heart failure. Lancet 1990;335(8681):63-6.

Coats 1992 \{published data only\} Coats AJ, Adamopoulos S, Radaelli A, McCance A, Meyer $\mathrm{TE}$, Bernardi $\mathrm{L}$, et al.Controlled trial of physical training in chronic heart failure. Exercise performance, hemodynamics, ventilation, and autonomic function. Circulation 1992;85 (6):2119-31.
Dubach et al studies \{published data only\}

Callaerts-Vegh Z, Wenk M, Goebbels U, Dziekan G, Myers

$\mathrm{J}$, Dubach $\mathrm{P}$, et al.Influence of intensive physical training on urinary nitrate elimination and plasma endothelin-1 levels in patients with congestive heart failure. Journal of Cardiopulmonary Rehabilitation 1998;18(6):450-7.

Dubach P, Myers J, Dziekan G, Goebbels U, Reinhart W, Muller P, et al.Effect of high intensity exercise training on central hemodynamic responses to exercise in men with reduced left ventricular function. Journal of the American College of Cardiology 1997;29(7):1591-8.

Duru F, Candinas R, Dziekan G, Goebbels U, Myers J, Dubach P. Effect of exercise training on heart rate variability in patients with new-onset left ventricular dysfunction after myocardial infarction. American Heart Journal 2000;140 (1):157-61.

Dziekan G, Myers J, Goebbels U, Muller P, Reinhart W, Ratti R, et al.Effects of exercise training on limb blood flow in patients with reduced ventricular function. American Heart Journal 1998;136(1):22-30.

Goebbels U, Myers J, Dziekan G, Muller P, Kuhn M, Ratte $\mathrm{R}$, et al.A randomized comparison of exercise training in patients with normal vs reduced ventricular function. Chest 1998;113(5):1387-93.

Myers J, Gianrossi R, Schwitter J, Wagner D, Dubach P. Effect of exercise training on postexercise oxygen uptake kinetics in patients with reduced ventricular function. Chest 2001;120(4):1206-11.

Myers J, Goebbels U, Dzeikan G, Froelicher V, Bremerich J, Mueller P, et al.Exercise training and myocardial remodeling in patients with reduced ventricular function: One-year follow-up with magnetic resonance imaging. American Heart Journal 2000;139(21):252-61.

Gottlieb 1999 \{published data only\} Gottlieb SS, Fisher ML, Freudenberger R, Robinson S, Zietowski G, Alves L, et al.Effects of exercise training on peak performance and quality of life in congestive heart failure patients. Journal of Cardiac Failure 1999;5(3): $188-94$. 
Hambrecht 1995 \{published data only\}

Hambrecht R, Niebauer J, Fiehn E, Kalberer B, Offner $\mathrm{B}$, Hauer K, et al.Physical training in patients with stable chronic heart failure: effects on cardiorespiratory fitness and ultrastructural abnormalities of leg muscles. Journal of the American College of Cardiology 1995;25(6):1239-49.

Hambrecht 1998 \{published data only\} Hambrecht R, Fiehn E, Weigl C, Gielen S, Hamann C, Kaiser R, et al.Regular physical exercise corrects endothelial dysfunction and improves exercise capacity in patients with chronic heart failure. Circulation 1998;98(24):2709-15.

Hambrecht 2000 \{published data only\}

Hambrecht R, Gielen S, Linke A, Fiehn E, Yu J, Walther $\mathrm{C}$, et al.Effects of exercise training on left ventricular function and peripheral resistance in patients with chronic heart failure: A randomized trial. JAMA 2000;283(23): 3095-101.

Jette 1991 \{published data only\} Jette M, Heller R, Landry F, Blumchen G. Randomized 4 week exercise program in patients with impaired left ventricular function. Circulation 1991;84(4):1561-7.

Keteyian 1996 \{published data only\}

Keteyian SJ, Levine AB, Brawner CA, Kataoka T, Rogers FJ, Schairer JR, et al.Exercise training in patients with heart failure. A randomized, controlled trial. Annals of Internal Medicine 1996;124(12):1051-7.

Kiilavuori 1996 \{published data only\}

Kiilavuori K, Sovijarvi A, Naveri H, Ikonen T, Leinonen $\mathrm{H}$. Effect of physical training on exercise capacity and gas exchange in patients with chronic heart failure. Chest 1996; 110(4):985-91.

\section{Maiorana 2000 \{published data only\}}

Maiorana A, O'Driscoll G, Cheetham C, Collis J, Goodman $\mathrm{C}$, Rankin $\mathrm{S}$, et al.Combined aerobic and resistance exercise training improves functional capacity and strength in CHF. Journal of Applied Physiology 2000;88(5):1565-70.

Meyer 1996 \{published data only\}

Meyer K, Schwaibold M, Westbrook S, Beneke R, Hajric R, Gornandt $\mathrm{L}$, et al.Effects of short-term exercise training and activity restriction on functional capacity in patients with severe chronic congestive heart failure. American Journal of Cardiology 1996;78(9):1017-22.

Meyer K, Schwaibold M, Westbrook S, Beneke R, Hajric R, Lehmann $\mathrm{M}$, et al.Effects of exercise training and activity restriction on 6-minute walking test performance in patients with chronic heart failure. American Heart Journal 1997; 133(4):447-53.

\section{Oka 2000 \{published data only\}} Oka RK, De Marco T, Haskell WL, Botvinick E, Dae MW, Bolen K, et al.Impact of a home-based walking and resistance training program on quality of life in patients with heart failure. American Journal of Cardiology 2000;85 (3):365-9.

\section{Owen 2000 \{published data only\}}

Owen A, Croucher L. Effect of an exercise programme for elderly patients with heart failure. European Journal of Heart Failure 2000;2(1):65-70.

Parnell 2002 \{published data only\} Parnell MM, Holst DP, Kaye DM. Exercise training increases arterial compliance in patients with congestive heart failure. Clinical Science 2002;102(1):1-7.

Ponikowski 1997 \{published data only\}

Ponikowski P, Szelemej R, Kowalska-Superlak M, Kratochwil D, Sobkowicz B, Sebzda T, et al.Exercise rehabilitation in patients with moderate-severe chronic heart failure. [CZY CHORZY Z NIEWYDOLNOSCIA KRAZENIA KORZYSTAJA Z REHABILITACJI RUCHOWEJ?]. Kardiologia Polska 1997;47(10):291-300.

Pu 2001 \{published data only\}

$\mathrm{Pu}$ CT, Johnson MT, Forman DE, Hausdorff JM, Roubenoff R, Foldvari M, et al.Randomized trial of progressive resistance training to counteract the myopathy of chronic heart failure. Journal of Applied Physiology 2001; 90(6):2341-50.

Quittan 1999 \{published data only\} Quittan M, Sturm B, Wiesinger GF, Pacher R, Fialka-Moser V. Quality of life in patients with chronic heart failure: a randomized controlled trial of changes induced by a regular exercise program. Scandinavian Journal of Rehabilitation Medicine 1999;31(4):223-8.

Sturm B, Quittan M, Wiesinger GF, Stanek B, Frey $\mathrm{B}$, Pacher R. Moderate-intensity exercise training with elements of step aerobics in patients with severe chronic heart failure. Archives of physical medicine and rehabilitation 1999;80:746-50.

Teo 1995 EXERT \{published data only\}

McKelvie RS, Teo KK, Roberts R, McCartney N, Humen D, Montague T, Hendrican K, Yusuf S. Effects of exercise training in patients with heart failure: The Exercise Rehabilitation Trial (EXERT). American heart journal 2002; 144(23-30).

Teo K, McKelvie R, Yusuf S, McCartney N, Guyatt G, Roberts R, et al.Randomized controlled trial of aerobic plus resistance exercise training in patients with congestive heart failure. The Exercise Rehab Trial (EXERT) Investigators [abstract]. Controlled clinical trials 1995;16(3 Suppl):99S.

Tyni-Lenne 1997 \{published data only\}

Tyni-Lenne R, Gordon A, Jansson E, Bermann G, Sylven C. Skeletal muscle endurance training improves peripheral oxidative capacity, exercise tolerance, and health-related quality of life in women with chronic congestive heart failure secondary to either ischemic cardiomyopathy or idiopathic dilated cardiomyopathy. American Journal of Cardiology 1997;80(8):1025-9.

Tyni-Lenne 2001 \{published data only\}

Tyni-Lenne R, Dencker K, Gordon A, Jansson E, Sylven C. Comprehensive local muscle training increases aerobic working capacity and quality of life and decreases 
neurohormonal activation in patients with chronic heart failure. European Journal of Heart Failure 2001;3(1):47-52.

Tyni-Lenne/Gordon 96 \{published data only\} Gordon A, Tyni-Lenne R, Persson H, Kaijser L, Hultman E, Sylven C. Markedly improved skeletal muscle function with local muscle training in patients with chronic heart failure. Clinical Cardiology 1996;19(7):568-74.

Tyni-Lenne R, Gordon A, Sylven C. Improved quality of life in chronic heart failure patients following local endurance training with leg muscles. Journal of Cardiac Failure 1996;2 (2):111-7.

Wielenga 1998 \{published data only\} Wielenga RP, Huisveld IA, Bol E, Dunselman PH, Erdman RA, Baselier MR, et al.Exercise training in elderly patients with chronic heart failure [published erratum appears in Coron Artery Dis 1999;10(1):57]. Coronary Artery Disease 1998;9(11):765-70.

Wielenga 1999 CHANGE \{published data only\} Wielenga RP, Huisveld IA, Bol E, Dunselman PH, Erdman RA, Baselier MR, et al.Safety and effects of physical training in chronic heart failure. Results of the Chronic Heart Failure and Graded Exercise study (CHANGE). European Heart Journal 1999;20(12):872-9.

Willenheimer 1998 \{published data only\} Willenheimer R, Erhardt L, Cline C, Rydberg E, Israelsson $B$. Exercise training in heart failure improves quality of life and exercise capacity. European Heart Journal 1998;19(5): 774-81.

\section{References to studies excluded from this review}

\section{Adamopoulos 1995 \{published data only\}}

Adamopoulos S, Ponikowski P, Cerquetani E, Piepoli M, Rosano G, Sleight P, et al.Circadian pattern of heart rate variability in chronic heart failure patients. Effects of physical training. European Heart Journal 1995;16(10): 1380-6.

Barnard 2000 \{published data only\} Barnard KL, Adams KJ, Swank AM, Kaelin M, Kushnik MR, Denny DM. Combined high-intensity strength and aerobic training in patients with congestive heart failure. Journal of strength and conditioning research 2000;14:383-8.

Belardinelli2 1995 \{published data only\} Belardinelli R, Georgiou D, Scocco V, Barstow TJ, Purcaro A. Low intensity exercise training in patients with chronic heart failure. Journal of the American College of Cardiology 1995;26(4):975-82.

Cohen-Solal 1994 \{published data only\} Cohen-Solal A, Aupetit JF, Gueret P, Kolsky H, Zannad F. Can anaerobic threshold be used as an end-point for therapeutic trials in heart failure? Lessons from a multicentre randomized placebo-controlled trial. The VO2 French Study Group. European Heart Journal 1994;15(2): 236-41.

\section{Davey 1992 \{published data only\}}

Davey P, Meyer T, Coats A, Adamopoulos S, Casadei B, Conway J, et al.Ventilation in chronic heart failure: Effects of physical training. British heart journal 1992;68(5):473-7.

Gordon 1999 \{published data only\} Gordon A, Tyni-Lenne R, Jansson E, Jensen-Urstad M, Kaijser L. Beneficial effects of exercise training in heart failure patients with low cardiac output response to exercise - a comparison of two training models. Journal of Internal Medicine 1999;246(2):175-82.

Johnson 1998 \{published data only\} Johnson PH, Cowley AJ, Kinnear WJ. A randomized controlled trial of inspiratory muscle training in stable chronic heart failure. European Heart Journal 1998;19(8): 1249-53.

\section{Kavanagh 1996 \{published data only\}} Kavanagh T, Myers MG, Baigrie RS, Mertens DJ, Sawyer P, Shephard RJ. Quality of life and cardiorespiratory function in chronic heart failure: effects of 12 months' aerobic training. Heart 1996;76(1):42-9.

Koch 1992 \{published data only\} Koch M, Douard H, Broustet JP. The benefit of graded physical exercise in chronic heart failure. Chest 1992;101(5 Suppl):231S-235S.

Metra 1998 \{published data only\} Metra M, Nodari S, Raccagni D, Garbellini M, Boldi E, Bontempi L, et al.Maximal and submaximal exercise testing in heart failure. Journal of Cardiovascular Pharmacology 1998;32(Suppl 1):S36-S45.

Page 1994 \{published data only\}

Page E, Cohen-Solal A, Jondeau G, Douard H, Roul G, Kantelip JP, et al.Comparison of treadmill and bicycle exercise in patients with chronic heart failure. Chest 1994; 106(4):1002-6.

Taylor 1999 \{published data only\}

Taylor A. Physiological response to a short period of exercise training in patients with chronic heart failure. Physiotherapy Research International 1999;4(4):237-49.

Tokmakova 1999 \{published data only\} Tokmakova M, Dobreva B, Kostianev S. Effects of shortterm exercise training in patients with heart failure. Folia Medica (Plovdiv) 1999;41(1):68-71.

Tyni-Lenne 1998 \{published data only\} Tyni-Lenne R, Gordon A, Europe E, Jansson E, Sylven C. Exercise-based rehabilitation improves skeletal muscle capacity, exercise tolerance, and quality of life in both women and men with chronic heart failure. Journal of Cardiac Failure 1998;4(1):9-17.

Tyni-Lenne 1999 \{published data only\} Tyni-Lenne R, Gordon A, Jensen-Urstad M, Dencker K, Jansson E, Sylven C. Aerobic training involving a minor muscle mass shows greater efficiency than training involving a major muscle mass in chronic heart failure patients. Journal of Cardiac Failure 1999;5(4):300-7. 


\section{References to studies awaiting assessment}

Kayanakis 1994 \{published data only\}

Kayanakis JG, Page E, Aros F, Borau F. [Rehabilitation of patients with chronic cardiac insufficiency. Immediate and midterm effects]. [French]. Presse Medicale 1994;23(3): $121-6$.

\section{References to ongoing studies}

NRR ongoing trial 1 \{published data only\}

National Research Register, Publication ID N0201112792. EXIST - Exercise Intervention Strategies in Heart Failure Trial. Start date 01/07/2002, end date 31/12/2002.

NRR ongoing trial 2 \{published data only\} National Research Register, Publication ID NO514100933. A randomised trial of exercise intervention for older patients with heart failure. Start date 01/01/2001, end date 01/01/ 2004 .

\section{Additional references}

AHA

American Heart Association. www.americanheart.org.

\section{CHF Guidelines 2001}

Working Group on Cardiac Rehabilitation and Exercise Physiology and Working Group on Heart Failure of the European Society of Cardiology. Recommendations for exercise training in chronic heart failure patients. European Heart Journal 2001;22:125-35.

\section{CHF Taskforce 2001}

The task force for the diagnosis and treatment of chronic heart failure. Guidelines for the diagnosis and treatment of chronic heart failure. European Heart Journal 2001;22: 1527-60.

\section{Cochrane Heart Group}

Cochrane Heart Group. Preferred method for handling continuous variables. http://www.epi.bris.ac.uk/cochrane/ stats3.html. Accessed May 2004.

\section{Conn 1982}

Conn EH, Williams RS, Wallace AG. Exercise responses before and after physical conditioning in patients with severely depressed left ventricular function. The American Journal of Cardiology 1982;49:296-300.

Cowie 1997

Cowie MR, Struthers AD, Wood DA, et al.Value of natriuretic peptides in the assessment of patients with possible new hear failure in primary care. Lancet 1997;350: 1349-53.

Dickersin 1994

Dickersin K, Scherer R, Lefebve C. Identifying relevant studies for systematic reviews. BMJ 1994;309:1286-91.

DOH 2000

National Service Framework for Coronary Heart Disease. http://www.doh.gov.uk/pdfs/chdnsf.pdf.
Drexler 1992

Drexler H, Riede U, Munzel T, Konig H, Funke E, Just $\mathrm{H}$. Alterations of skeletal muscle in chronic heart failure. Circulation 1992;85:1751-9.

Dziekan 1998

Dziekan G, Myers J, Goebbels U, Muller P, Reinhart W, Ratti R, et al.Effects of exercise training on limb blood flow in patients with reduced ventricular function. American Heart Journal 1998;136:22-7.

Follmann 1992

Follman D, Elliot P, Suh I, Cutler J. Variance imputation for overviews of clinical trials with continuous response. Journal of Clinical Epidemiology 1992;45:769-73.

Hülsmann 2002

Hülsmann M, Berger R, Sturm B, Bojic A, Woloszczuk W, Bergler-Klein, et al.Prediction of outcome by neurohumoral activation, the six-minute walk test and the Minnesota living with heart failure questionnaire in an outpatient cohort with congestive heart failure. European Heart Journal 2002;23:886-91.

Jadad 1996 Jadad AR, Moore A, Carroll D, Jenkinson C, Reynolds JM, Gavaghan DJ, et al.Assessing the quality of reports of clinical trials: Is blinding necessary?. Controlled Clinical Trials 1996;17(1):1-12.

Jolliffe 2001

Jolliffe JA, Rees K, Taylor RS, Thompson D, Oldridge N, Ebrahim S. Exercise based rehabilitation for coronary heart disease (Cochrane Review). The Cochrane Library 2001, Issue 2.

Kannel 1991 Kannel WB, Belanger AJ. Epidemiology of heart failure. American Heart Journal 1991;121:951-7.

Kostis 1997

Kostis JB, Davis BR, Cutler J, et al.Prevention of heart failure antihypertensive drug treatment in older persons with isolated systemic hypertension. SHEP Cooperative Research Group. JAMA 1997;278(3):212-6.

Lee 1979

Lee AP, Ice R, Blessey R, Sanmarco ME. Long term effects of physical training on coronary patients with impaired ventricular function. Circulation 1979;60(1519-26).

\section{Lefebvre 1996}

Lefebvre C, McDonald S. Development of a sensitive search strategy for reports of randomised controlled trials in EMBASE. Conference Abstracts for the Fourth International Cochrane Colloquium, 20-24 Oct; Adelaide, Australia. 1996.

Lip 2000

Lip GYH, Gibbs CR, Beevers DG. Aetiology: ABC of heart failure. $B M J$ 2000;320:104-7.

\section{Lloyd-Williams 2002}

Lloyd-Williams F, Mair FS, Leitner M. Exercise training and heart failure: A systematic review of current evidence. British Journal of General Practice 2002;52(474):47-55. 


\section{Mancini 1992}

Mancini DM, Walter G, Reichek N, et al.Contribution of skeletal muscle atrophy to exercise intolerance and altered muscle metabolism in heart failure. Circulation 1992;85: 1364-73.

\section{McMurray 2000}

McMurray JJ, Steward S. Heart failure: Epidemiology, aetiology, and prognosis of heart failure. Heart 2000;83: 596-602.

\section{NHS 1998}

NHS Centre for Reviews and Dissemination. Cardiac Rehabilitation. Effective Health Care Bulletin 1998;4.

\section{O'Connor 1989}

O'Connor GT, Buring JE, Yusuf S, Goldhaber SZ, Olmstead EM, Paffenbarger RS, et al.An overview of randomised trials of rehabilitation with exercise after myocardial infarction. Circulation 1989;80:234-44.

\section{Oldridge 1988}

Oldridge NB, Guyatt GH, Fischer ME, Rimm AA. Cardiac rehabilitation after myocardial infarction. Combined experience of randomised clinical trials. JAMA 1988;260: 945-50.

\section{Opasich 2001}

Opasich C, Pinna GD, Mazza A, Febo O, Riccardi R, Riccardi PG, et al.Six-minute walking performance in patients with moderate-to-severe heart failure; is it a useful indicator in clinical practice?. European Heart Journal 2001; 22(6):445-8.

\section{Rees 2004}

Rees K, Bennett PD, West RR, Davey-Smith G, Ebrahim S. Psychological Interventions for coronary heart disease. The Cochrane Library 2004, Issue 2.

\section{Sullivan 1988}

Sullivan MJ, Higginbotham MB, Cobb FR. Exercise training in patients with severe left ventricular dysfunction: hemodynamic and metabolic effects. Circulation 1988;78: 506-15.

\section{Sullivan 1989}

Sullivan MJ, Knight D, Higginbotham MB, Cobb FR. Relation between central and peripheral hemodynamics during exercise in patients with chronic heart failure. Circulation 1989;80:769-81.

\section{van den Brock 1992}

van den Brock SA, van Veldhuisen DJ, de Graeff PA, Landsman ML, Hillege H, Lie KI. Comparison between New York Heart Association classification and peak oxygen consumption in the assessment of functional status and prognosis in patients with mild to moderate chronic congestive heart failure secondary to either ischemic or idiopathic dilated cardiomyopathy. American Journal of Cardiology 1992;70:359-63.

\section{Watson 2000}

Watson RDS, Gibbs CR, Lip GYH. ABC of heart failure: clinical features and complications. BMJ 2000;320:236-9.

* Indicates the major publication for the study 


\section{CHARACTERISTICS OFSTUDIES}

\section{Characteristics of included studies [ordered by study ID]}

\section{Belardinelli 1992}

\begin{tabular}{l|l}
\hline Methods & Parallel group RCT \\
\hline Participants & . HF diagnosis mixed, $\mathrm{n}=12$ IHD, $\mathrm{n}=8 \mathrm{DCM}$. LVEF $<40 \%$. 20 patients randomised, mean age 61.5 years, 90\% men \\
\hline Interventions & $\begin{array}{l}\text { Aerobic exercise in outpatient setting for } 8 \text { weeks, } 3 \text { times a week for one hour. Workload was prgressively increased } \\
\text { from } 40 \% \text { VO } 2 \text { max to } 65 \% \text { in the last week. Follow-up assessment at end of intervention period of } 8 \text { weeks }\end{array}$ \\
\hline Outcomes & Exercise duration \\
\hline Notes & Been translated from Italian publication \\
\hline
\end{tabular}

\section{Belardinelli 1995}

\begin{tabular}{ll}
\hline Methods & Parallel group RCT \\
\hline Participants & $\begin{array}{l}\text { HF diagnosis mixed }-\mathrm{n}=18 \mathrm{IHD}, \mathrm{n}=37 \text { DCM, NYHA class } 2 \text { or } 3.55 \text { patients randomised, } 85 \% \text { men, mean age } \\
55 \text { years }\end{array}$ \\
\hline Interventions & $\begin{array}{l}\text { Aerobic exercise, } 1 \text { hour } 3 \text { times a week for } 8 \text { weeks on a bike ergometer, intensity altered according to individuals } \\
\text { progression, patients monitored by telemetry. Follow-up assessment at } 12 \text { months }\end{array}$ \\
\hline Outcomes & $\begin{array}{l}\text { VO2max } \\
\text { Peak workload }\end{array}$ \\
\hline Notes & \\
\hline
\end{tabular}

Belardinelli 1999

\begin{tabular}{ll}
\hline Methods & Parallel group RCT \\
\hline Participants & $\begin{array}{l}\text { HF diagnosis mixed }-85 \% \text { ischaemic cardiomyopathy, } 15 \% \text { idiopathic DCM, LVEF <40\%. 99 patients randomised, } \\
89 \% \text { men, mean age } 59 \text { years }\end{array}$ \\
\hline Interventions & $\begin{array}{l}\text { Aerobic exercise - } 2 \text { phases }-8 \text { week programme and } 12 \text { months maintainance programme. Phase } 1 \text { - warm up } \\
\text { stretching } 15-20 \text { minutes, } 40 \text { mins on bike ergometer for at } 60 \% \text { VO2max, } 5 \text { minutes cool down, } 3 \text { times a week. } \\
\text { Phase } 2 \text { - repeat of phase } 1 \text { but } 2 \text { times a week for remaining } 12 \text { months. Compliance from attendance at sessions - } \\
\text { 89\%. Follow-up measurement at } 14 \text { months (repeat exercise test), patients monitored for } 3.3 \text { years }\end{array}$ \\
\hline Outcomes & $\begin{array}{l}\text { VO2max } \\
\text { HRQoL }\end{array}$ \\
\hline Notes & \\
\hline
\end{tabular}


Cider 1997

\begin{tabular}{ll}
\hline Methods & Parallel group RCT \\
\hline Participants & $\begin{array}{l}\text { Mixed CHF patients, most secondary to IHD. NYHA class } 2 \text { or 3, CHF diagnosis for at least a year. 24 patients } \\
\text { randomised, 67\% men, mean age } 63 \text { years }\end{array}$ \\
\hline Interventions & $\begin{array}{l}\text { Strength/resistance training - peripheral dynamic training (circuit weight training regimen } 60 \% 1 \text { rep maximum), 60 } \\
\text { minutes, } 2 \text { times a week for } 5 \text { months. Compliance } 75 \% \text {. Follow-up assessment at end of intervention at } 5 \text { months }\end{array}$ \\
\hline Outcomes & HRQoL \\
\hline Notes & \\
\hline
\end{tabular}

\section{Coats 1990}

\begin{tabular}{|c|c|}
\hline Methods & Cross over RCT \\
\hline Participants & $\begin{array}{l}\text { All patients had diagnosis of } \mathrm{HF} \text { secondary to } \mathrm{MI}, \mathrm{LVEF}<40 \% .11 \text { patients randomised, all men, mean age } 63 \text { (7.6) } \\
\text { years }\end{array}$ \\
\hline Interventions & $\begin{array}{l}\text { Aerobic exercise on bike ergometer at } 70-80 \% \text { max HR. } 1 \text { minute warm up, } 20 \text { minutes cycling, } 1 \text { minute cool down, } \\
5 \text { days a week for } 8 \text { weeks. Exercise performed at home - patients given a HR monitor. Control group asked to avoid } \\
\text { exercise over and above their normal level, particularly if it caused breathlessness or fatigue. Following crossover from } \\
\text { the trained group, bikes were taken from them and the same activity restriction was recommended. Data has been } \\
\text { combined for the } 2 \text { arms, but the authors explicitly state there were no carry over effects. Compliance to exercise was } \\
\text { monitored by bike revolutions (mean compliance } 74 \% \text { ). Followed up at the end of the intervention at } 16 \text { weeks }\end{array}$ \\
\hline Outcomes & $\begin{array}{l}\text { VO2 max } \\
\text { Exercise duration }\end{array}$ \\
\hline Notes & \\
\hline
\end{tabular}

Coats 1992

\begin{tabular}{ll}
\hline Methods & Cross over RCT \\
\hline Participants & $\begin{array}{l}\text { All patients had diagnosis of HF secondary to MI, LVEF<40\%, NYHA class } 2 \text { or 3. } 19 \text { patients randomised, all men, } \\
\text { mean age } 61.8 \text { years }\end{array}$ \\
\hline Interventions & $\begin{array}{l}\text { Aerobic exercise on bike ergometer at } 50 \mathrm{rpm} \text { for } 20 \mathrm{mins} 5 \text { times a week for } 8 \text { weeks. Bikes used at home by the } \\
\text { patient - given HR monitor. Compliance from bike revolutions - mean } 77.3 \% \text {. Control group asked to avoid exercise } \\
\text { over and above their current level, particularly if it caused dyspnoea. Data combined for the } 2 \text { arms of the trial, but } \\
\text { the authors explicitly state there were no carry-over effects. Followed up at the end of the intervention at } 16 \text { weeks }\end{array}$ \\
\hline Outcomes & $\begin{array}{l}\text { VO2 max } \\
\text { Exercise duration }\end{array}$ \\
\hline Notes &
\end{tabular}


Dubach et al studies

\begin{tabular}{|c|c|}
\hline Methods & Parallel group RCT \\
\hline Participants & $\begin{array}{l}\text { CHF secondary to CHD - all patients had had a prior MI, NYHA class } 2 \text { or } 3 \text {, LVEF }<40 \% .25 \text { patients randomised, } \\
\text { all men, mean age } 55 \text { years }\end{array}$ \\
\hline Interventions & $\begin{array}{l}\text { Aerobic exercise - } 8 \text { week residential course in Swiss mountains. Comprehensive rehabilitation including exercise, } \\
\text { education and a low fat diet. Outdoor walking for } 1 \text { hour twice a day, stationary cycling } 4 \text { times a week for } 45 \\
\text { minutes at } 70-80 \% \text { HR reserve. Follow-up assessment at end of intervention period of } 8 \text { weeks }\end{array}$ \\
\hline Outcomes & $\begin{array}{l}\text { VO2max } \\
\text { Exercise time } \\
\text { Exercise capacity }\end{array}$ \\
\hline \multicolumn{2}{|l|}{ Notes } \\
\hline \multicolumn{2}{|l|}{ Gottlieb 1999} \\
\hline Methods & Parallel group RCT \\
\hline Participants & $\begin{array}{l}\text { Mixed CHF - primary } n=18 \text {, ischaemic } n=7 \text {, NYHA } 2 \text { or } 3 \text {, LVEF }<40 \% .33 \text { patients randomised, } 88 \% \text { men, age } \\
\text { range } 64-67 \text { years }\end{array}$ \\
\hline Interventions & $\begin{array}{l}\text { Aerobic exercise, } 6 \text { months supervised training } 3 \text { times a week, cycling and treadmill walking, exercise progressively } \\
\text { increased to perceived exertion of } 12-13 \text { on the Borg Scale. Compliance } 75 \% \text {. Outcome assessment at end of } \\
\text { intervention period of } 6 \text { months }\end{array}$ \\
\hline Outcomes & $\begin{array}{l}\text { VO2 max } \\
\text { Exercise duration } \\
\text { Distance on } 6 \text { minute walk }\end{array}$ \\
\hline Notes & \\
\hline
\end{tabular}

\section{Hambrecht 1995}

\begin{tabular}{ll}
\hline Methods & Parallel group RCT \\
\hline Participants & $\begin{array}{l}\text { Majority of patients DCM (19/22), remainder IHD. NYHA class } 2 \text { or 3, LVEF <40\%. 22 patients randomised, all } \\
\text { men, mean age } 51 \text { years }\end{array}$ \\
\hline Interventions & $\begin{array}{l}\text { Aerobic exercise, } 3 \text { weeks in hospital, remainder of } 6 \text { months at home, and group sessions. Hospital - } 10 \text { minutes } \\
6 \text { times a day for } 3 \text { weeks on a bike ergometer under strict supervision, workload } 70 \% \text { VO2max. Home - asked } \\
\text { to exercise close to target HR (bikes and pulse rate monitoring equipment loaned to patients) twice a day for } 40 \\
\text { minutes, plus also attend } 2 \text { group sessions per week for } 1 \text { hour each. Follow-up at end of the intervention period of } \\
6 \text { months }\end{array}$ \\
\hline Outcomes & $\begin{array}{l}\text { VO2 max } \\
\text { Exercise duration }\end{array}$
\end{tabular}




\section{Hambrecht 1995 (Continued)}

Notes

\section{Hambrecht 1998}

\begin{tabular}{ll} 
Methods & Parallel group RCT \\
\hline Participants & $\begin{array}{l}\text { Mixed CHF - DCM n=13, CHD n=7, NYHA } 2 \text { or 3, LVEF<40\%. 20 patients randomised, all men, mean age 55 } \\
\text { years }\end{array}$ \\
\hline $\begin{array}{l}\text { Interventions } \\
\text { Aerobic exercise, } 3 \text { weeks on an individual care ward and remaining } 6 \text { months at home. } 3 \text { weeks - bike ergometer } 6 \\
\text { times daily for } 10 \text { minutes at } 70 \% \text { VO2max. Home - patient took bike ergometer home to exercise } 5 \text { times a week } \\
\text { for } 40 \text { minutes (total of twice daily), and attend } 1 \text { group session per week. Compliance to home training estimated } \\
\text { to be } 70 \% . \text { Follow-up assessment at end of intervention period of } 6 \text { months }\end{array}$ \\
\hline Outcomes & VO2max \\
\hline Notes &
\end{tabular}

\section{Hambrecht 2000}

\begin{tabular}{ll}
\hline Methods & Parallel group RCT \\
\hline Participants & $\begin{array}{l}\text { Majority of patients DCM (61/73), remainder IHD. LVEF <40\%. } 73 \text { patients randomised, all men, mean age 54.5 } \\
\text { years }\end{array}$ \\
\hline Interventions & $\begin{array}{l}\text { Aerobic exercise, } 2 \text { weeks on an individual care ward and remaining } 6 \text { months at home. } 2 \text { weeks - bike ergometer 4- } \\
6 \text { times daily for } 10 \text { minutes at } 70 \% \text { VO2max. Home - patient took bike ergometer home to exercise } 5 \text { times a week } \\
\text { for } 20 \text { minutes at } 70 \% \text { VO2max, and attend } 1 \text { group session per week of } 1 \text { hour duration. Follow-up assessment at } \\
\text { end of intervention period of } 6 \text { months }\end{array}$ \\
\hline Outcomes & $\begin{array}{l}\text { VO2 max } \\
\text { Exercise duration }\end{array}$ \\
\hline Notes &
\end{tabular}

\section{Jette 1991}

\begin{tabular}{ll}
\hline Methods & Parallel group RCT \\
\hline Participants & CHF secondary to MI, NYHA 2 or 3 and LVEF $<50 \% .39$ patients randomised, all men, mean age 50.8 years \\
\hline Interventions & $\begin{array}{l}\text { Aerobic exercise } 5 \text { days a week for } 4 \text { weeks - jogging } 5 \text { mins } 3 \text { times a day, cycling } 15 \text { mins (both at } 70-80 \% \text { max } \\
\text { HR), calisthenics (30 mins) and relaxation training (20 mins). Follow-up assessment at end of intervention period } \\
\text { at } 4 \text { weeks }\end{array}$ \\
\hline Outcomes & $\begin{array}{l}\text { VO2max } \\
\text { Peak workload }\end{array}$ \\
\hline Exercise based rehabilitation for heart failure (Review)
\end{tabular}


Jette 1991 (Continued)

Notes

\section{Keteyian 1996}

\begin{tabular}{ll}
\hline Methods & Parallel group RCT \\
\hline Participants & $\begin{array}{l}\text { Mixed CHF - IHD (n=9) and DCM (n=20) CHF patients, NYHA } 2 \text { or 3, LVEF 35\% or less. All men, mean age 54 } \\
\text { years }\end{array}$ \\
\hline Interventions & $\begin{array}{l}\text { Aerobic exercise, } 45 \text { minutes (5 mins warm up, } 35 \text { mins } 3 \text { types aerobic activity, } 5 \text { mins cool down) } 3 \text { times a week } \\
\text { for } 24 \text { weeks. Follow-up measurements at } 24 \text { weeks }\end{array}$ \\
\hline Outcomes & $\begin{array}{l}\text { VO2max } \\
\text { Exercise duration }\end{array}$ \\
\hline Notes & \\
\hline
\end{tabular}

\section{Kiilavuori 1996}

\begin{tabular}{l|l}
\hline Methods & Parallel group RCT \\
\hline Participants & $\begin{array}{l}\text { Mixed CHF - CHD }(n=9) \text { and DCM }(n=18), \text { NYHA } 2 \text { or 3, LVEF }<40 \% .27 \text { patients randomised, } 96 \% \text { men, mean } \\
\text { age } 52 \text { years }\end{array}$ \\
\hline
\end{tabular}

Interventions Aerobic exercise - 3 months supervised, 3 months home based. Supervised - bike ergometer 30 mins 3 times a week at 50-60\% VO2max for 2-3 weeks, then increased workload depending on individual HR thereafter. Home based - walking, rowing, cycling or swimming depending on individual instruction. Control group advised not to change their previous physical activity during the 6 months. Follow-up assessment at 6 months

$\begin{array}{ll}\text { Outcomes } & \text { VO2max } \\ & \text { Exercise duration }\end{array}$

Notes

\section{Maiorana 2000}

\begin{tabular}{ll}
\hline Methods & Cross over RCT \\
\hline Participants & $\begin{array}{l}\text { Mixed CHF, n=7 CHD, n=6 DCM, NYHA 1-3, LVEF mean 26\%. } 13 \text { patients randomised, all men, mean age } 60 \\
\text { years }\end{array}$ \\
\hline Interventions & $\begin{array}{l}\text { Aerobic and resistance training. } 8 \text { weeks training, } 1 \text { hour } 3 \text { times a week. Whole body exercise concentrating on } \\
\text { the large muscle groups. Combination of circuit training, cycle ergometry, treadmill and resistance weight training. } \\
\text { Intensity and duration of exercise gradually increased over the } 8 \text { week period. Follow-up assessment at } 16 \text { weeks (cross } \\
\text { over trial) }\end{array}$
\end{tabular}


Maiorana 2000 (Continued)

\begin{tabular}{|c|c|}
\hline Outcomes & $\begin{array}{l}\mathrm{VO} 2 \mathrm{max} \\
\text { Exercise duration }\end{array}$ \\
\hline \multicolumn{2}{|l|}{ Notes } \\
\hline \multicolumn{2}{|l|}{ Meyer 1996} \\
\hline Methods & Cross over RCT \\
\hline Participants & $\begin{array}{l}\text { Severe CHF, patients are hospitalised. Mix of CHF due to DCM }(n=9) \text { and IHD }(n=9) .18 \text { patients randomised, all } \\
\text { men, mean age } 52 \text { years }\end{array}$ \\
\hline Interventions & $\begin{array}{l}\text { Aerobic and resistance training. } 3 \text { weeks in hospital training on bike ergometer and treadmill at } 50 \% \text { max work } \\
\text { rate, } 10-15 \text { minutes } 3-5 \text { times per week for each exercise respectively. Also muscle strength exercises, coordination } \\
\text { and inspiratory muscle training } 3 \text { times a week for } 20 \text { minutes. Follow up after } 6 \text { week intervention period. Data } \\
\text { presented combined for the } 2 \text { arms, but authors explicitly state that no evidence of carry-over effects was found }\end{array}$ \\
\hline Outcomes & $\begin{array}{l}\text { VO2 max } \\
\text { Peak workload (Watts) }\end{array}$ \\
\hline Notes & \\
\hline
\end{tabular}

\section{Oka 2000}

\begin{tabular}{ll}
\hline Methods & Parallel group RCT \\
\hline Participants & Mixed CHF, LVEF <40\%. 40 patients randomised, 77.5\% men, age range 30-76 years \\
\hline Interventions & $\begin{array}{l}\text { Aerobic and resistance training at home for } 3 \text { months. Walking at home } 3 \text { times a week increasing the intensity and } \\
\text { duration over the initial 2-3 weeks to } 70 \% \text { peak HR for } 40-60 \text { minutes. Total body unilateral resistance exercises } \\
2 \text { times a week up to } 75 \% 1 \text { rep max. Weekly phonecalls to answer questions and monitor adherence. Follow-up } \\
\text { assessment at end of intervention period of } 3 \text { months }\end{array}$ \\
\hline Outcomes & $\begin{array}{l}\text { VO2max } \\
\text { Exercise duration } \\
\text { HRQoL }\end{array}$ \\
\hline Notes & \\
\hline
\end{tabular}

Owen 2000

\begin{tabular}{ll}
\hline Methods & Cross over RCT \\
\hline Participants & $\begin{array}{l}\text { Mixed aetiology of CHF, 67\% CHD, 33\% AF, LVEF }<40 \% \text {. Focus on the elderly }>75 \text { years, mean age } 81 \text { years, } 75 \% \\
\text { men. 22 patients randomised }\end{array}$
\end{tabular}




\section{Owen 2000 (Continued)}

\begin{tabular}{ll} 
Interventions & $\begin{array}{l}\text { Resistance training - } 6 \text { station circuit with stations alternating between stamina and strengthening exercises. Patients } \\
\text { worked in a range comfortable to them and warned not to exceed } 70 \% \text { max HR (showed how to monitor this). } \\
\text { Average session } 1 \text { hour, once a week for } 12 \text { weeks. Follow-up assessment at end of intervention period at } 24 \text { weeks } \\
\text { (cross over trial) }\end{array}$ \\
\hline Outcomes & Distance on 6 min walk \\
\hline Notes & \\
\hline
\end{tabular}

\section{Parnell 2002}

Methods Parallel group RCT

Participants Mixed aetiology of CHF, NYHA 2 or 3. 21 patients randomised, $91 \%$ men, age range $53-57$ years

Interventions Aerobic exercise - 8 weeks of walking, cycling and light weights at 50-60\% maximum HR, increasing exercise duration progressively from 30 mins-60 mins per day for 5-7 days per week. Follow-up assessment at end of intervention period of 8 weeks

Outcomes Distance on 6 min walk HRQoL

Notes

Ponikowski 1997

\begin{tabular}{ll} 
Methods & Parallel group RCT \\
\hline Participants & $\begin{array}{l}\text { Mixed aetiology of CHF, most (88\%) CHD, 12\% DCM, LVEF <45\%. } 32 \text { patients randomised, 81\% men, mean } \\
\text { age } 57 \text { years }\end{array}$ \\
\hline Interventions & $\begin{array}{l}\text { Aerobic exercise training - first 1-2 weeks in hospital, following modified Royal Canadian Airforce Training pro- } \\
\text { gramme, and graded walking, under the supervision of a physiotherapist (max HR 75-80\%). 35-45 mins exercise } \\
\text { per day. For remaining } 16 \text { weeks, similar walking programme to be done individually at home for } 6 \text { days each week. } \\
\text { Comparison group - usual care. Follow-up assessment at end of } 16 \text { weeks }\end{array}$ \\
\hline Outcomes & $\begin{array}{l}\text { VO2max } \\
\text { Exercise duration } \\
\text { Peak workload (Watts) } \\
\text { Clinical outcomes. } \\
\text { HRQoL }\end{array}$ \\
\hline Notes & \begin{tabular}{l} 
Been translated from Polish publication \\
\hline
\end{tabular}
\end{tabular}




\begin{tabular}{|c|c|}
\hline Methods & Parallel group RCT \\
\hline Participants & $\begin{array}{l}\text { Mixed group of mild-moderate CHF, ischaemic and idiopathic, NYHA class 1-3. All women over the age of } 65 \text { years } \\
\text { (mean } 77 \text { years), } 16 \text { patients randomised }\end{array}$ \\
\hline Interventions & $\begin{array}{l}\text { Resistance training - high intensity progressive training } 3 \text { times a week for } 10 \text { weeks, } 1 \text { hour sessions. Dynamic } \\
\text { contraction of large upper and lower body groups, at } 80 \% \text { weight that could be lifted in good form ( } 1 \text { repetition } \\
\text { max). Control group received "placebo" controlled stretching. Attendance at classes averaged } 98 \% \text { in both groups. } \\
\text { Follow-up assessment at end of intervention period of } 10 \text { weeks }\end{array}$ \\
\hline Outcomes & $\begin{array}{l}\text { VO2max } \\
\text { Distance on } 6 \text { min walk }\end{array}$ \\
\hline \multicolumn{2}{|l|}{ Notes } \\
\hline \multicolumn{2}{|l|}{ Quittan 1999} \\
\hline Methods & Parallel group RCT \\
\hline Participants & All DCM patients, NYHA 2 or $3, \mathrm{LVEF}<30 \% .25$ patients randomised, $81.5 \%$ men, mean age 55.3 years \\
\hline Interventions & $\begin{array}{l}\text { Aerobic exercise programme - } 3 \text { months bike ergometer training and step exercises } 1 \text { hour (short warm up and cool } \\
\text { down and } 2 \text { times } 25 \text { minutes training) } 2-3 \text { times per week, at } 50 \% \text { maximal functional capacity. Follow up assessment } \\
\text { at end of intervention period of } 3 \text { months }\end{array}$ \\
\hline Outcomes & $\begin{array}{l}\text { VO2max } \\
\text { Exercise duration } \\
\text { HRQoL }\end{array}$ \\
\hline Notes & \\
\hline
\end{tabular}

\section{Teo 1995 EXERT}

\begin{tabular}{ll} 
Methods & Parallel group RCT \\
\hline Participants & $\begin{array}{l}\text { Mixed CHF, for majority of patients CHD (76\%), NYHA 1-3, LVEF }>40 \% .181 \text { patients randomised, 81\% men, } \\
\text { mean age } 65.5 \text { years }\end{array}$ \\
\hline Interventions & $\begin{array}{l}\text { Aerobic and resistance training in supervised rehabilitation programme for } 3 \text { months and continued home based } \\
\text { training for a further } 9 \text { months. Aerobic training HR set at } 60-70 \% \text { maximum HR. Cycle, treadmill and arm } \\
\text { ergometry exercise for } 30 \text { mins per session twice a week and walking at home once a week. Supervised resistance } \\
\text { training twice a week at } 40-60 \% 1 \text { repetition maximum - arm curls, knee extensions and leg press. After } 3 \text { months } \\
\text { patients provided with a bike and set of free weight and instructed to train } 3 \text { times a week for remaining } 9 \text { months. } \\
\text { Follow-up assessment at } 12 \text { months }\end{array}$
\end{tabular}

Outcomes Distance on 6 min walk HRQoL 


\section{Teo 1995 EXERT (Continued)}

Notes

Tyni-Lenne 1997

\begin{tabular}{ll}
\hline Methods & Cross over RCT \\
\hline Participants & $\begin{array}{l}\text { Aetiology of CHF both CHD }(\mathrm{n}=8) \text { and DCM }(\mathrm{n}=8) \text {. NYHA class } 2 \text { or 3, LVEF<40\%. 16 patients randomised - } \\
\text { all women, mean age } 62 \text { years }\end{array}$ \\
\hline Interventions & $\begin{array}{l}\text { Endurance training of leg muscles } 3 \text { times a week for } 8 \text { weeks on a modified knee extensor ergometer. } 15 \text { minutes } \\
\text { at } 60 \text { reps per minutes intensity progressively increasing from } 65-75 \% \text { peak work rate. Follow-up at the end of } 16 \\
\text { weeks (crossover study) }\end{array}$ \\
\hline Outcomes & $\begin{array}{l}\text { VO2 max } \\
\text { Distance on } 6 \text { minute walk }\end{array}$ \\
\hline Notes & Contacted authors re: QoL data \\
\hline
\end{tabular}

Tyni-Lenne 2001

\begin{tabular}{ll}
\hline Methods & Parallel group RCT \\
\hline Participants & $\begin{array}{l}\text { Aetiology of CHF both CHD and DCM. LVEF }<40 \% \text { and NYHA class } 2 \text { or 3. } 24 \text { patients randomised, 54\% men, } \\
\text { mean age } 62.5 \text { years. Randomisation to intervention 2:1 }\end{array}$ \\
\hline Interventions & $\begin{array}{l}\text { Strength/resistance exercise using resistance rubber bands. } 8 \text { weeks supervised group exercise } 3 \text { times a week for } 1 \\
\text { hour. } 6 \text { minutes warm up, } 45 \text { minutes training - continuous repetitive contractions against a resistance - one muscle } \\
\text { group at a time with } 25 \text { reps, } 9 \text { minutes cool down. Compliance measured as attendance - 95\%. Follow-up assessment } \\
\text { at the end of the } 8 \text { week intervention period }\end{array}$ \\
\hline Outcomes & $\begin{array}{l}\text { VO2 max } \\
\text { Distance on } 6 \text { minute walk HRQoL }\end{array}$ \\
\hline Notes & \\
\hline
\end{tabular}

Tyni-Lenne/Gordon 96

\begin{tabular}{ll}
\hline Methods & Parallel group RCT \\
\hline Participants & Aetiology of CHF both CHD and DCM. NYHA class 2 or 3.21 patients randomised, all men, mean age 60 years \\
\hline Interventions & $\begin{array}{l}\text { Endurance training with continuous knee extensor exercises at } 60 \text { reps per minute performed on a modified bike } \\
\text { ergometer. Two intervention groups - } 1 \text { legged exercise and } 2 \text { legged exercise where the same relative quantity of } \\
\text { muscle work per session was performed, but the quantity of muscle mass activated was different. } 8 \text { weeks of training } \\
3 \text { times a week for } 25-40 \text { minutes. Compliance estimated to be between } 90-100 \% \text {. Follow-up assessment at the end } \\
\text { of the intervention period at } 8 \text { weeks }\end{array}$
\end{tabular}




\section{Tyni-Lenne/Gordon 96 (Continued)}

\begin{tabular}{|c|c|}
\hline Outcomes & $\begin{array}{l}\text { Distance on } 6 \text { minute walk } \\
\text { HRQoL } \\
\text { VO2max (Gordon 96) }\end{array}$ \\
\hline Notes & Assuming same study as Gordon $1996 . \mathrm{VO} 2 \mathrm{max}$ measured in that study \\
\hline \multicolumn{2}{|l|}{ Wielenga 1998} \\
\hline Methods & Parallel group RCT \\
\hline Participants & $\begin{array}{l}\text { Aetiology of CHF both CHD and DCM. LVEF }<40 \% \text { and NYHA class } 2 \text { or } 3.67 \text { patients randomised, all men, } \\
\text { mean age } 64 \text { years. Patients stratified and outcomes expressed in terms of those greater and less than } 65 \text { years of age }\end{array}$ \\
\hline Interventions & $\begin{array}{l}\text { Aerobic exercise training - } 12 \text { weeks training } 3 \text { times a week - } 45 \text { minute sessions of walking, cycling and ball games } \\
10 \text { mins each with } 5 \text { mins rest. Target HR maintained for at least } 20 \text { minutes. Follow-up assessment at end of } \\
\text { intervention period of } 12 \text { weeks }\end{array}$ \\
\hline Outcomes & $\begin{array}{l}\text { VO2max } \\
\text { Exercise duration }\end{array}$ \\
\hline Notes & \\
\hline
\end{tabular}

\section{Wielenga 1999 CHANGE}

\begin{tabular}{ll}
\hline Methods & Parallel group RCT \\
\hline Participants & $\begin{array}{l}\text { Aetiology of CHF both CHD and DCM. LVEF }<40 \% \text { and NYHA class } 2 \text { or 3. } 80 \text { patients randomised, all men, } \\
\text { mean age } 56.6 \text { years }\end{array}$
\end{tabular}

Interventions Aerobic exercise, 12 weeks training 3 times a week, comprising 3 exercises for 10 mins each separated by 5 mins rest (cycling, walking and ball games), at 60\% max HR. Walking progressed to slow running during the course of the training period. $85.4 \%$ compliance. Follow-up assessment at end of the intervention period of 12 weeks

\begin{tabular}{ll}
\hline Outcomes & VO2max \\
& Exercise duration \\
\hline
\end{tabular}

Notes

\section{Willenheimer 1998}

Methods Parallel group RCT

Participants Aetiology of CHF both CHD (75\%) and DCM. Boston HF criteria and LVEF <45\%. 54 patients randomised, 71. $5 \%$ men, mean age 64 years 
Interventions Aerobic exercise - 16 weeks interval training on a bike ergometer - 90 seconds exercise at $80 \%$ VO2 max, 30 seconds rest. Exercise time gradually increased from 15 minutes total 2 times a week to 45 minutes 3 times a week from week 7. Mean compliance $74.5 \%$. Follow-up assessment at end of intervention period of 16 weeks

$\begin{array}{ll}\text { Outcomes } & \text { VO2max } \\ & \text { Peak workload (Watts) }\end{array}$

Notes

AF: atrial fibrillation

CHF: chronic heart failure

CHD: coronary heart disease

DCM : dilated cardiomyopathy

HR: heart rate

HRQoL: health related quality of life

LVEF: left ventricular ejection fraction

Mins: minutes

NYHA: New York Heart Association classification

QoL: quality of life

RCT : randomised controlled trial

VO2max: peak oxygen uptake

Characteristics of excluded studies [ordered by study ID]

\begin{tabular}{l|l}
\hline Study & Reason for exclusion \\
\hline Adamopoulos 1995 & No relevant outcomes \\
\hline Barnard 2000 & No relevant outcomes \\
\hline Belardinelli2 1995 & Not an RCT \\
\hline Cohen-Solal 1994 & Not an RCT \\
\hline Davey 1992 & $\begin{array}{l}\text { As stated in Coats 1992, there is overlap in some of the patients taking part in each trial. Efforts have been } \\
\text { made to obtain data for those that participated only in the Davey trial but these studies were conducted over } \\
10 \text { years ago. To be conservative we have excluded this study from the analyses }\end{array}$ \\
\hline Gordon 1999 & Exercise versus exercise comparison - not usual care \\
\hline Johnson 1998 & Inspiratory muscle training, not whole body training \\
\hline Kavanagh 1996 & Not an RCT
\end{tabular}


(Continued)

Koch 1992 Only relevant outcome was QoL with little detail given in the paper. Written to the authors for the data available but no response

Metra $1998 \quad$ Not an RCT

Page $1994 \quad$ Exercise versus exercise comparison - not usual care

Taylor $1999 \quad$ No baseline data were presented in the publication for the outcomes of interest. Written to authors to try to obtain these, but no response

Tokmakova 1999 No data were presented for the control group in the publication. Written to authors to try to obtain these, but no response

Tyni-Lenne $1998 \quad$ Not an RCT

Tyni-Lenne 1999 Patients were previously trained 
DATA ANDANALYSES

Comparison 1. All exercise interventions versus usual care

\begin{tabular}{|c|c|c|c|c|}
\hline Outcome or subgroup title & $\begin{array}{l}\text { No. of } \\
\text { studies }\end{array}$ & $\begin{array}{c}\text { No. of } \\
\text { participants }\end{array}$ & Statistical method & Effect size \\
\hline 1 Cardiac mortality & 1 & 99 & Odds Ratio (M-H, Fixed, 95\% CI) & $0.32[0.13,0.80]$ \\
\hline 2 Non-fatal Myocardial Infarction & 1 & 99 & Odds Ratio (M-H, Fixed, 95\% CI) & $0.48[0.04,5.47]$ \\
\hline $\begin{array}{l}3 \text { Hospital readmission for Heart } \\
\text { Failure }\end{array}$ & 1 & 99 & Odds Ratio (M-H, Fixed, 95\% CI) & $0.28[0.09,0.85]$ \\
\hline $\begin{array}{l}4 \text { Deaths not associated with } \\
\text { training but reported reasons } \\
\text { for loss to follow-up }\end{array}$ & 9 & 483 & Odds Ratio (M-H, Fixed, 95\% CI) & $1.12[0.58,2.15]$ \\
\hline $5 \mathrm{VO} 2 \mathrm{max}(\mathrm{ml} / \mathrm{kg} / \mathrm{min})$ & 24 & 848 & Mean Difference (IV, Random, 95\% CI) & $-2.16[-2.82,-1.49]$ \\
\hline 6 Exercise duration (mins) & 15 & 510 & Mean Difference (IV, Fixed, 95\% CI) & $-2.38[-2.85,-1.92]$ \\
\hline 7 Maximum work capacity (Watts) & 6 & 219 & Mean Difference (IV, Fixed, 95\% CI) & $\begin{array}{l}-15.13[-17.67,-12 . \\
59]\end{array}$ \\
\hline $\begin{array}{l}8 \text { Distance on } 6 \text { minute walk } \\
\text { (meters) }\end{array}$ & 8 & 282 & Mean Difference (IV, Random, 95\% CI) & $\begin{array}{l}-40.87[-64.65,-17 . \\
10]\end{array}$ \\
\hline
\end{tabular}

\section{Comparison 2. Subgroup analyses}

\begin{tabular}{|c|c|c|c|c|}
\hline Outcome or subgroup title & $\begin{array}{l}\text { No. of } \\
\text { studies }\end{array}$ & $\begin{array}{c}\text { No. of } \\
\text { participants }\end{array}$ & Statistical method & Effect size \\
\hline $1 \mathrm{VO} 2 \max (\mathrm{ml} / \mathrm{kg} / \mathrm{min})$ & 24 & 4191 & Mean Difference (IV, Random, 95\% CI) & $-2.19[-2.48,-1.90]$ \\
\hline $\begin{aligned} & 1.1 \text { "Dose" of intervention } \\
= & />30 \text { units }\end{aligned}$ & 11 & 432 & Mean Difference (IV, Random, 95\% CI) & $-2.78[-3.88,-1.69]$ \\
\hline $\begin{array}{l}1.2 \text { "Dose" of intervention < } \\
30 \text { units }\end{array}$ & 13 & 416 & Mean Difference (IV, Random, 95\% CI) & $-1.64[-2.15,-1.12]$ \\
\hline 1.3 Jadad score $=3$ and above & 7 & 341 & Mean Difference (IV, Random, 95\% CI) & $-2.01[-2.90,-1.12]$ \\
\hline 1.4 Jadad score $=2$ and below & 15 & 458 & Mean Difference (IV, Random, 95\% CI) & $-2.28[-3.47,-1.10]$ \\
\hline $\begin{array}{l}\text { 1.5 Duration of intervention } \\
>12 \text { weeks }\end{array}$ & 10 & 420 & Mean Difference (IV, Random, 95\% CI) & $-2.62[-3.76,-1.48]$ \\
\hline $\begin{array}{l}\text { 1.6 Duration of intervention } \\
=/<12 \text { weeks }\end{array}$ & 14 & 428 & Mean Difference (IV, Random, 95\% CI) & $-1.79[-2.33,-1.24]$ \\
\hline 1.7 Mean age $>55$ years & 15 & 540 & Mean Difference (IV, Random, 95\% CI) & $-1.77[-2.50,-1.03]$ \\
\hline 1.8 Mean age $=\mid<55$ years & 9 & 308 & Mean Difference (IV, Random, 95\% CI) & $-2.95[-4.25,-1.64]$ \\
\hline $\begin{array}{l}\text { 1.9 Duration of follow up > } \\
16 \text { weeks }\end{array}$ & 9 & 397 & Mean Difference (IV, Random, 95\% CI) & $-2.74[-3.83,-1.65]$ \\
\hline $\begin{aligned} & 1.10 \text { Duration of follow up } \\
= & /<16 \text { weeks }\end{aligned}$ & 15 & 451 & Mean Difference (IV, Random, 95\% CI) & $-1.55[-2.17,-0.94]$ \\
\hline
\end{tabular}

Exercise based rehabilitation for heart failure (Review) 
Analysis I.I. Comparison I All exercise interventions versus usual care, Outcome I Cardiac mortality.

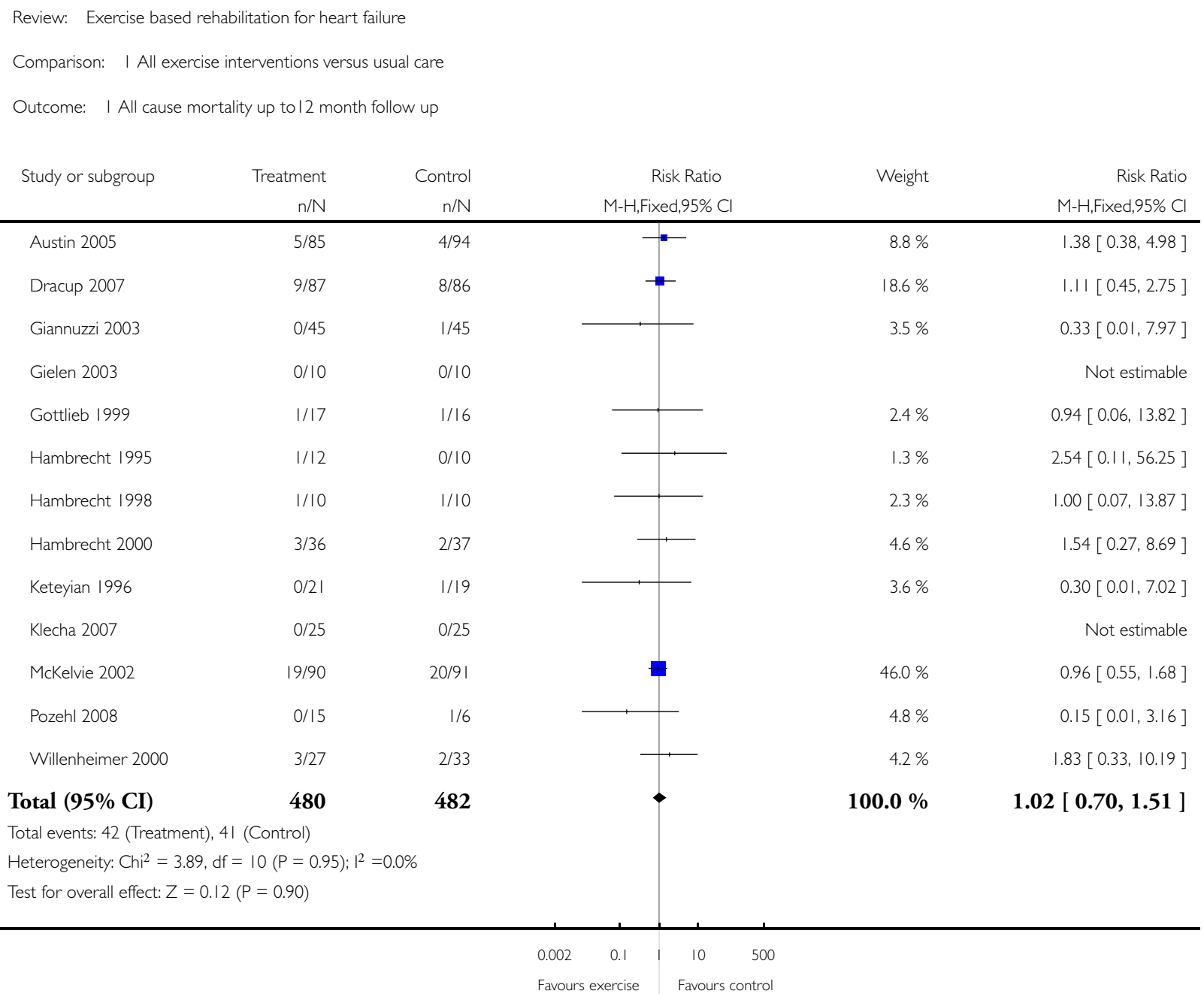


Analysis I.2. Comparison I All exercise interventions versus usual care, Outcome 2 Non-fatal Myocardial Infarction.

Review: Exercise based rehabilitation for heart failure

Comparison: I All exercise interventions versus usual care

Outcome: 2 All cause mortality more than 12 months follow up

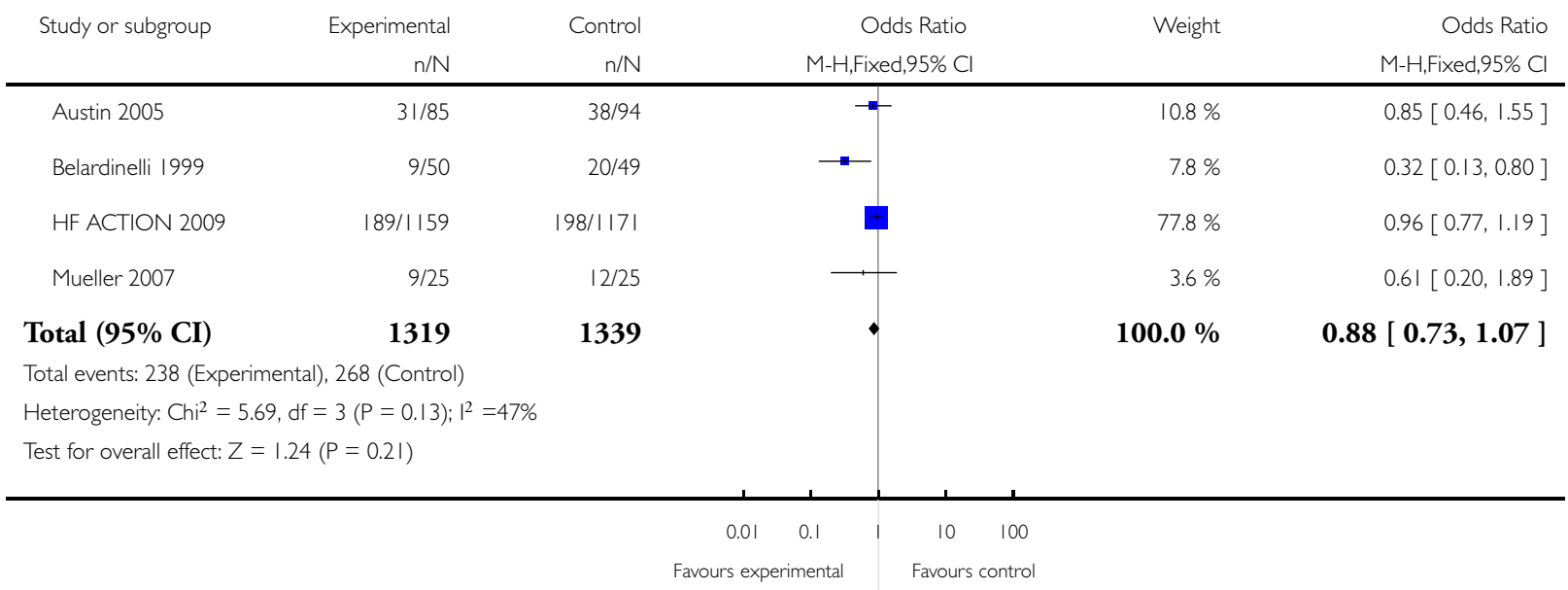


Analysis I.3. Comparison I All exercise interventions versus usual care, Outcome 3 Hospital readmission for Heart Failure.

Review: Exercise based rehabilitation for heart failure

Comparison: I All exercise interventions versus usual care

Outcome: 3 Hospital admission up to 12 month follow up

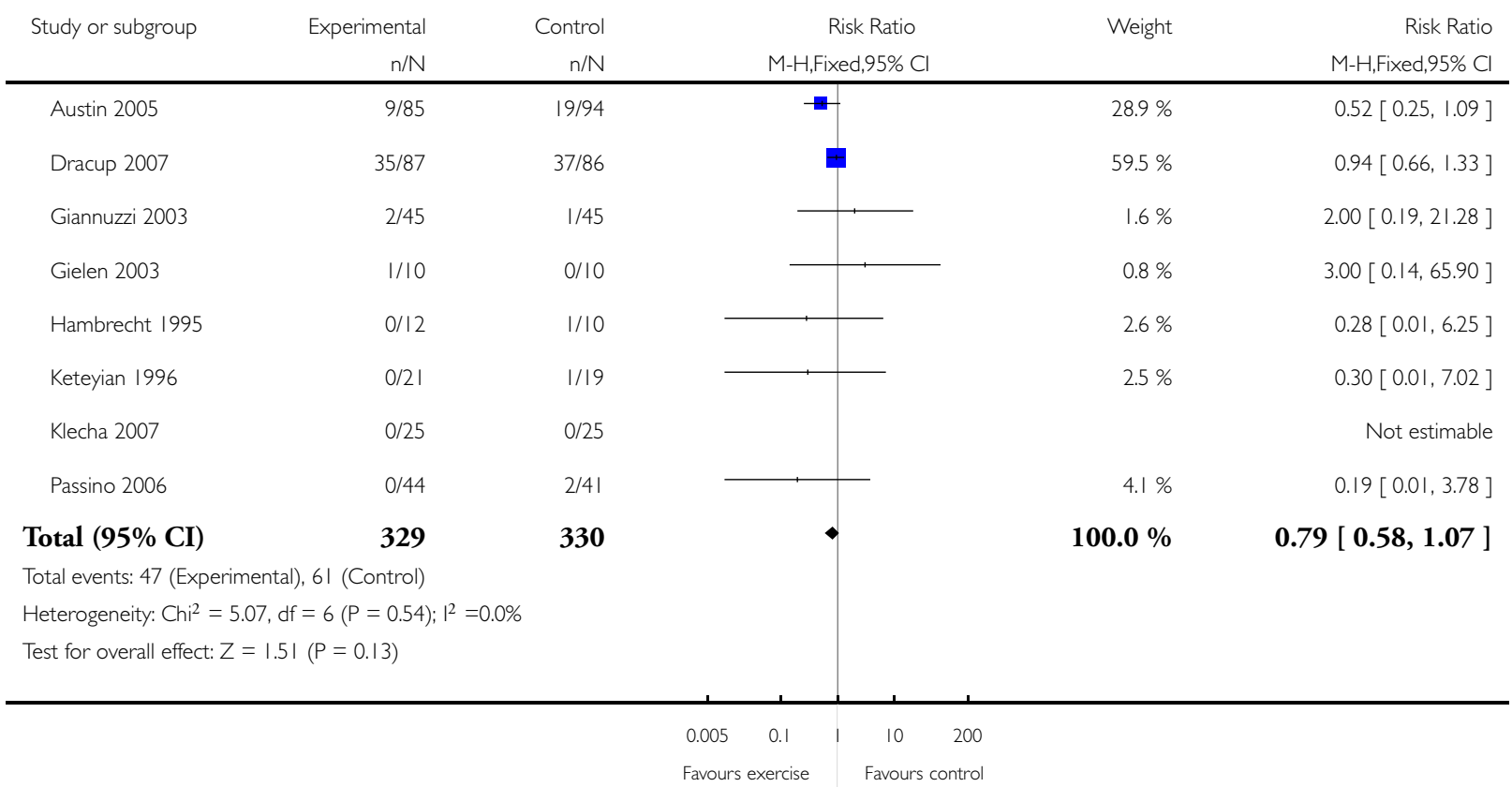


Analysis I.4. Comparison I All exercise interventions versus usual care, Outcome 4 Deaths not associated with training but reported reasons for loss to follow-up.

Review: Exercise based rehabilitation for heart failure

Comparison: I All exercise interventions versus usual care

Outcome: 4 Hospital admission more than 12 months follow up

\begin{tabular}{|c|c|c|c|c|c|}
\hline \multirow[t]{2}{*}{ Study or subgroup } & Treatment & Control & Risk Ratio & \multirow[t]{2}{*}{ Weight } & Risk Ratio \\
\hline & $n / N$ & $n / N$ & M-H,Fixed,95\% Cl & & M-H,Fixed, $95 \% \mathrm{Cl}$ \\
\hline Austin 2005 & $28 / 85$ & $33 / 94$ & + & $3.9 \%$ & $0.94[0.62,1.41]$ \\
\hline Belardinelli 1999 & $5 / 50$ & $14 / 49$ & 一 & $1.8 \%$ & $0.35[0.14,0.90]$ \\
\hline HF ACTION 2009 & $729 / 1159$ & $760 / 1171$ & $=$ & $94.0 \%$ & $0.97[0.91,1.03]$ \\
\hline Mueller 2007 & $2 / 25$ & $3 / 25$ & & $0.4 \%$ & $0.67[0.12,3.65]$ \\
\hline Total $(95 \%$ CI $)$ & 1319 & 1339 & 1 & $100.0 \%$ & $0.96[0.90,1.02]$ \\
\hline \multicolumn{6}{|c|}{ Total events: 764 (Treatment), 810 (Control) } \\
\hline \multicolumn{6}{|c|}{ Heterogeneity: $\mathrm{Ch}^{2}=4.74, \mathrm{df}=3(P=0.19) ; \mathrm{I}^{2}=37 \%$} \\
\hline \multicolumn{6}{|c|}{ Test for overall effect: $Z=1.45(P=0.15)$} \\
\hline
\end{tabular}


Analysis I.5. Comparison I All exercise interventions versus usual care, Outcome 5 VO2 max (ml/kg/min).

Review: Exercise based rehabilitation for heart failure

Comparison: I All exercise interventions versus usual care

Outcome: 5 Hospital admission heart failure only

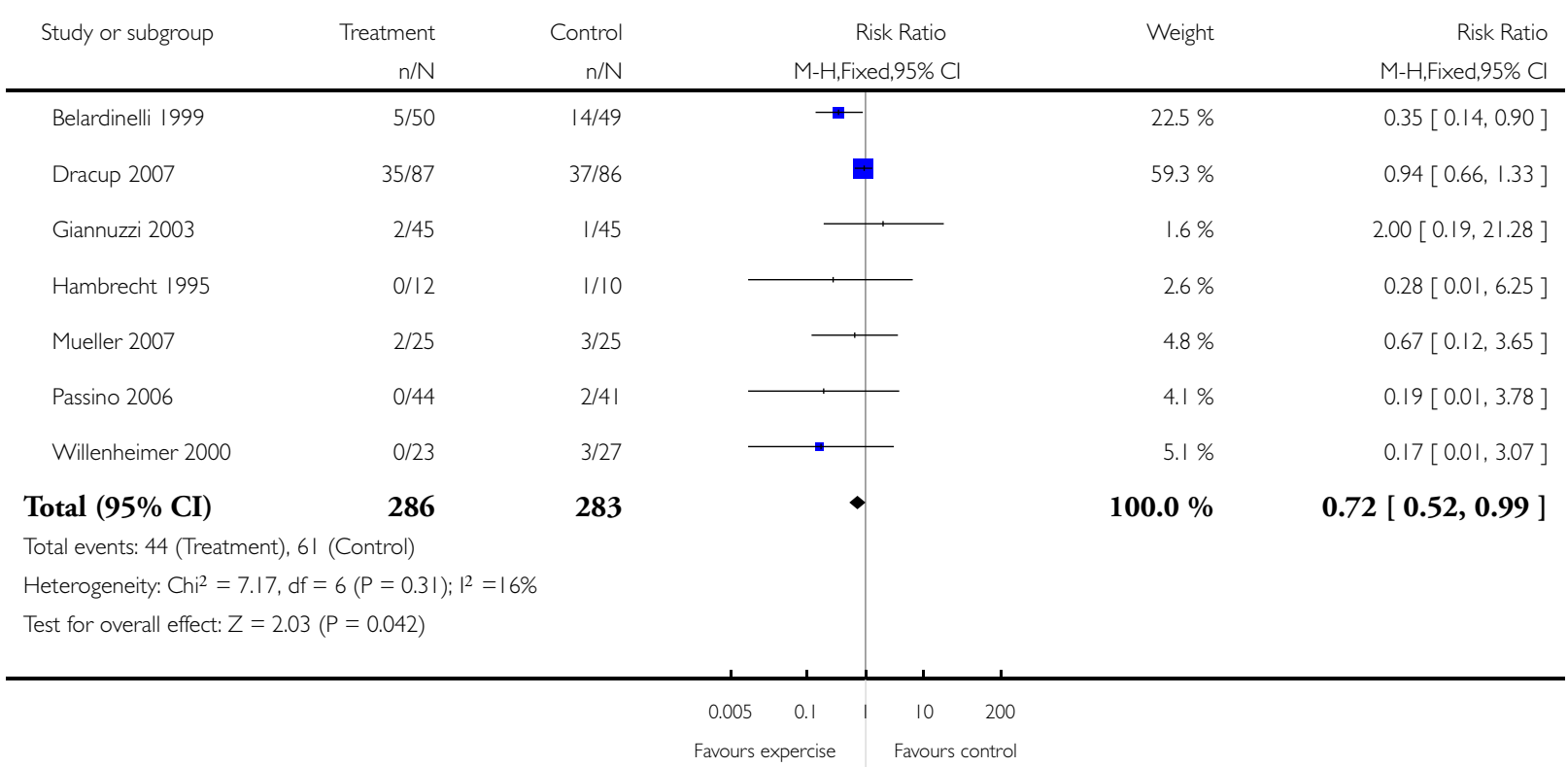


Analysis I.6. Comparison I All exercise interventions versus usual care, Outcome 6 Exercise duration (mins).

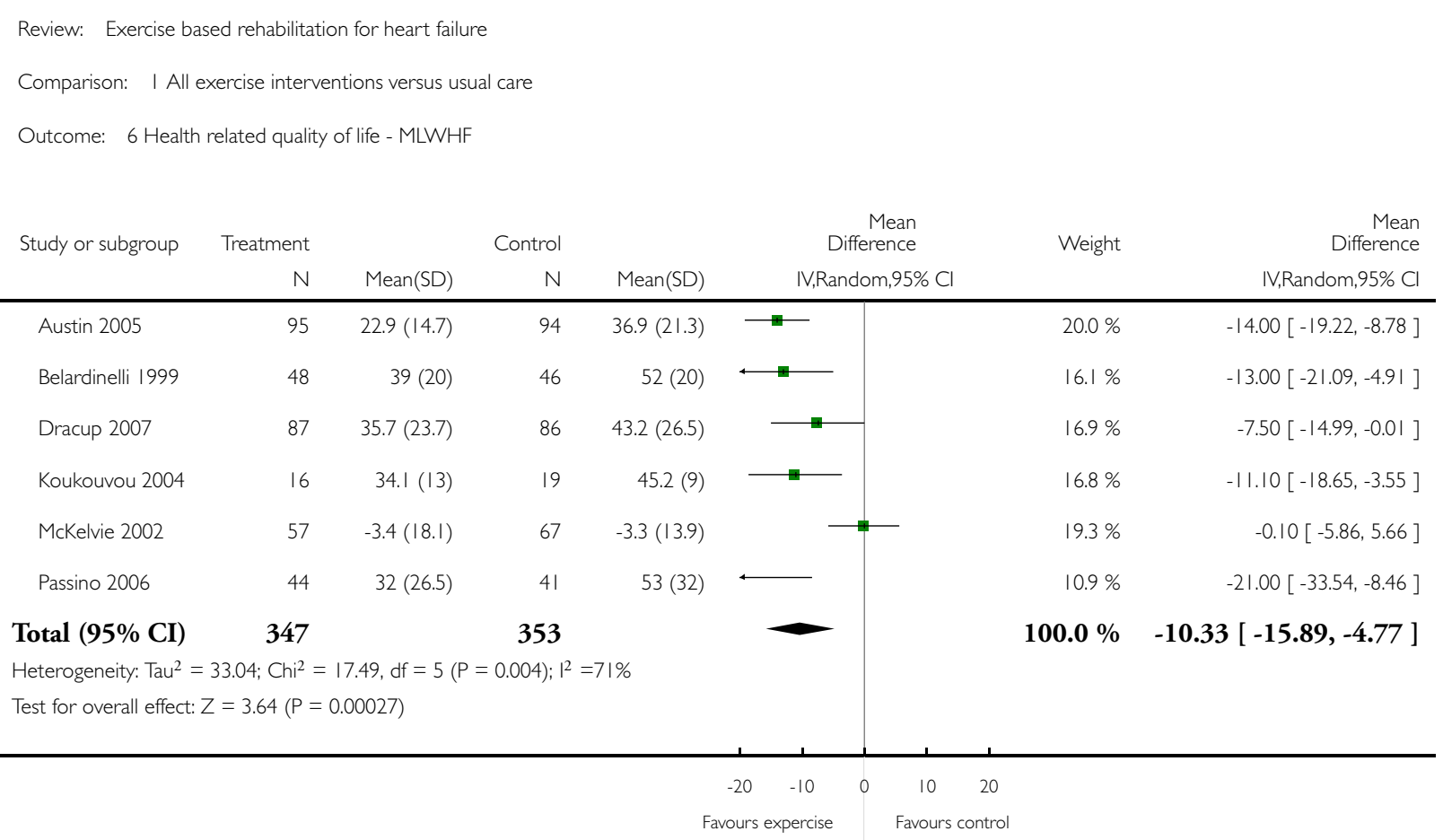


Analysis I.7. Comparison I All exercise interventions versus usual care, Outcome 7 Maximum work capacity (Watts).

Review: Exercise based rehabilitation for heart failure

Comparison: I All exercise interventions versus usual care

Outcome: 7 Health related quality of life - all scales

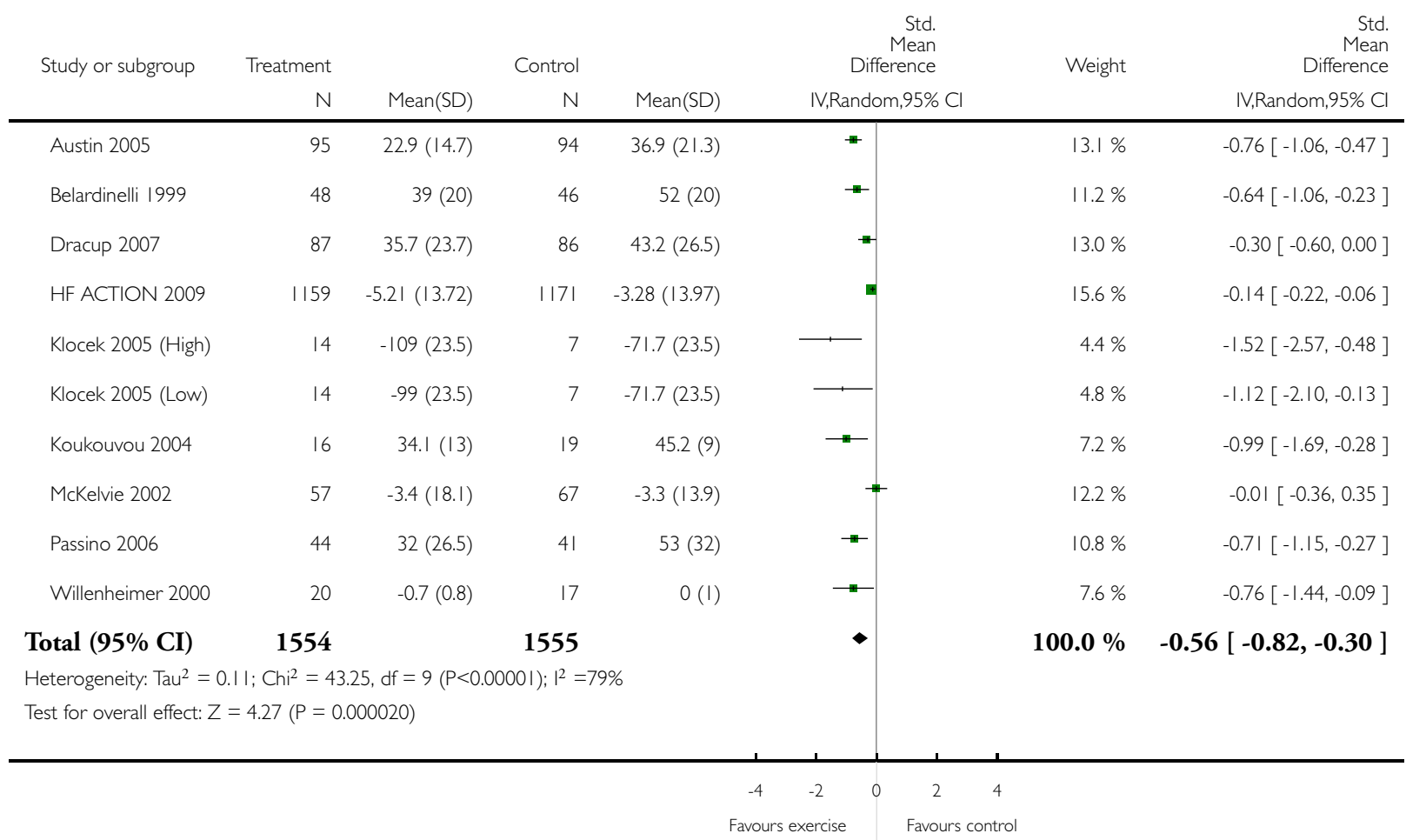




\section{Analysis I.8. Comparison I All exercise interventions versus usual care, Outcome 8 Distance on 6 minute walk (meters).}

Review: Exercise based rehabilitation for heart failure

Comparison: I All exercise interventions versus usual care

Outcome: 8 Distance on 6 minute walk (meters)

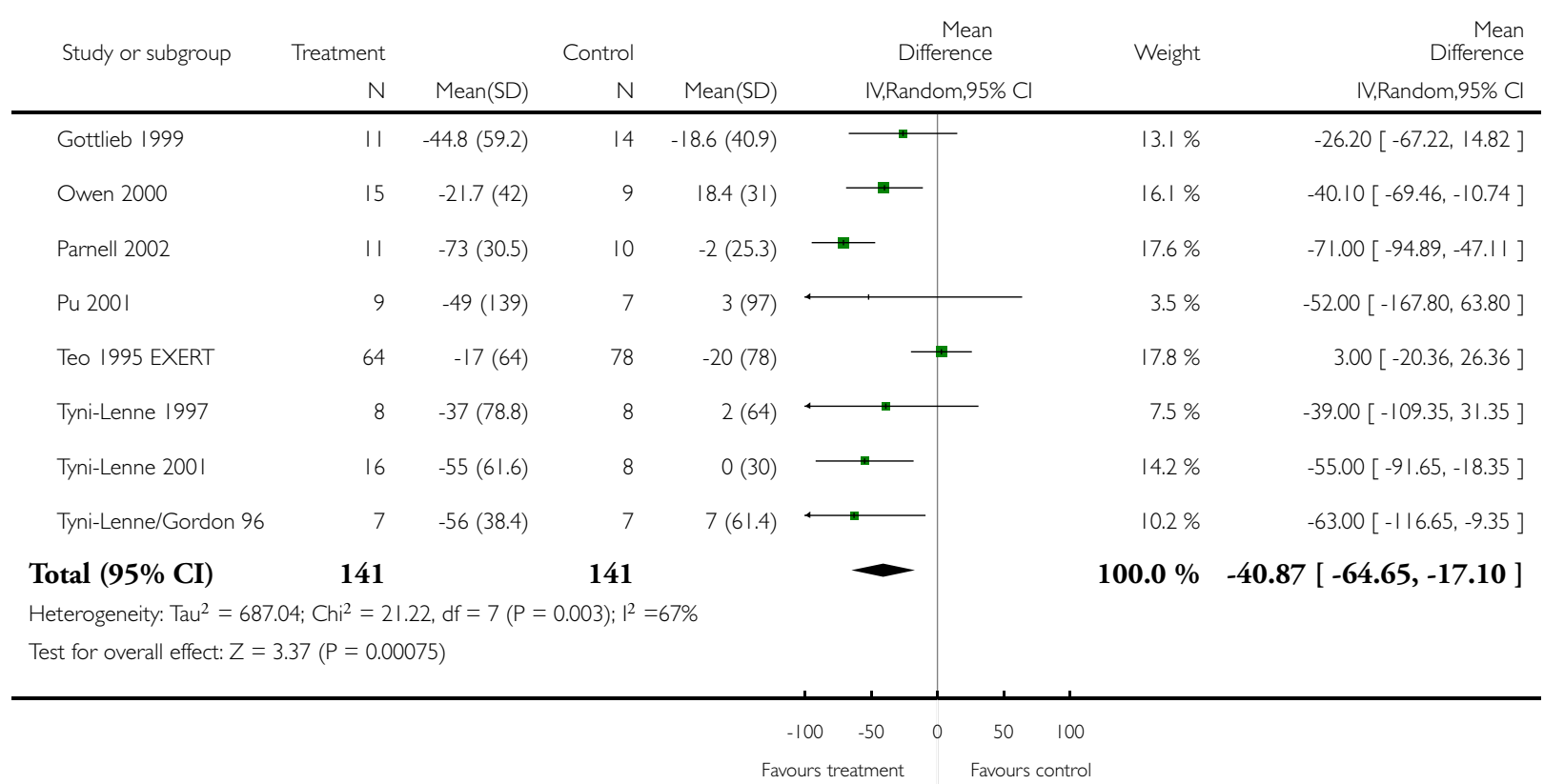




\section{Analysis 2.I. Comparison 2 Subgroup analyses, Outcome I VO2 $\max (\mathrm{ml} / \mathrm{kg} / \mathrm{min})$.}

Review: Exercise based rehabilitation for heart failure

Comparison: 2 Subgroup analyses

Outcome: I VO2 $\max (\mathrm{ml} / \mathrm{kg} / \mathrm{min})$

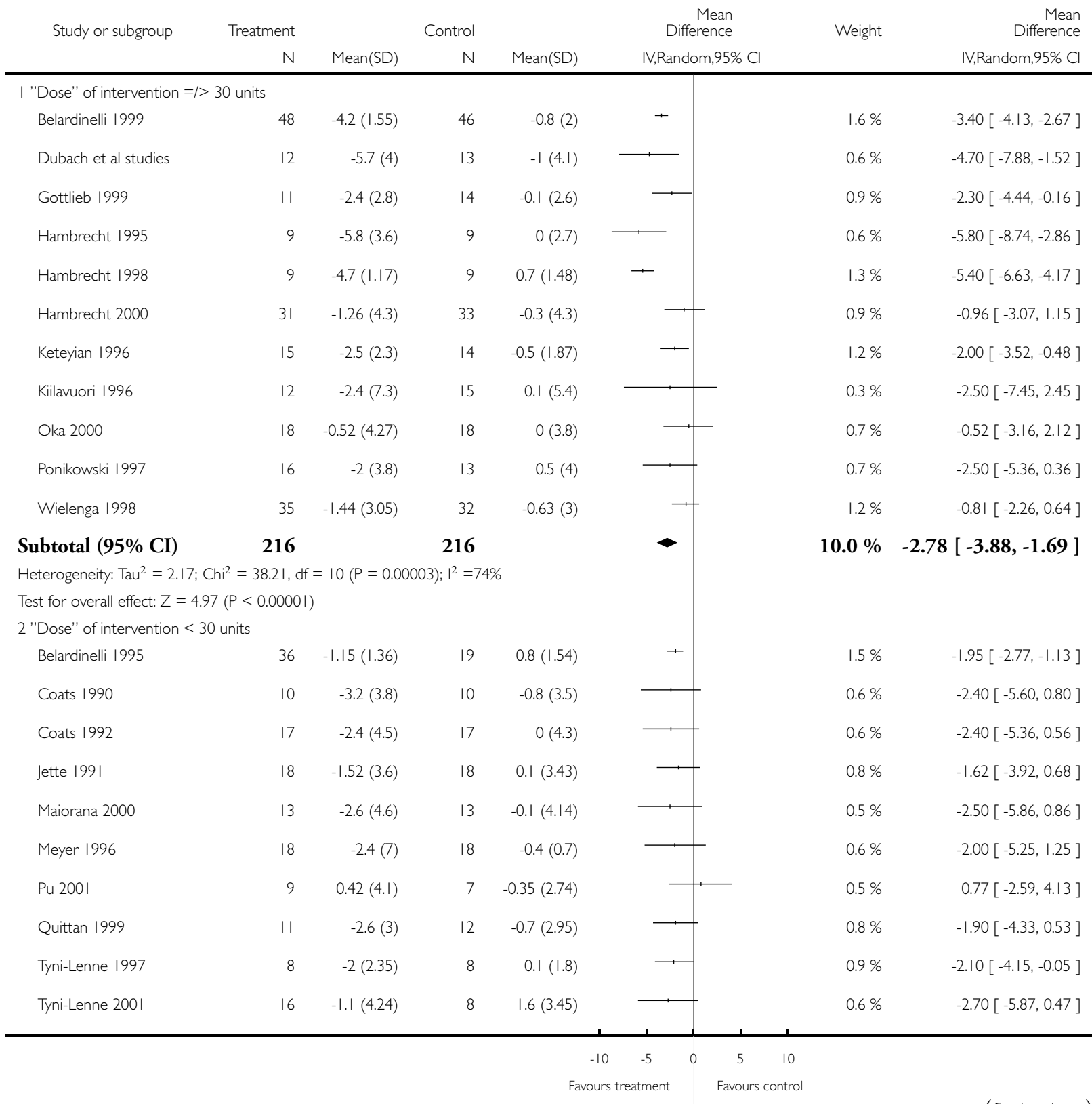

(Continued ...)

Exercise based rehabilitation for heart failure (Review) 


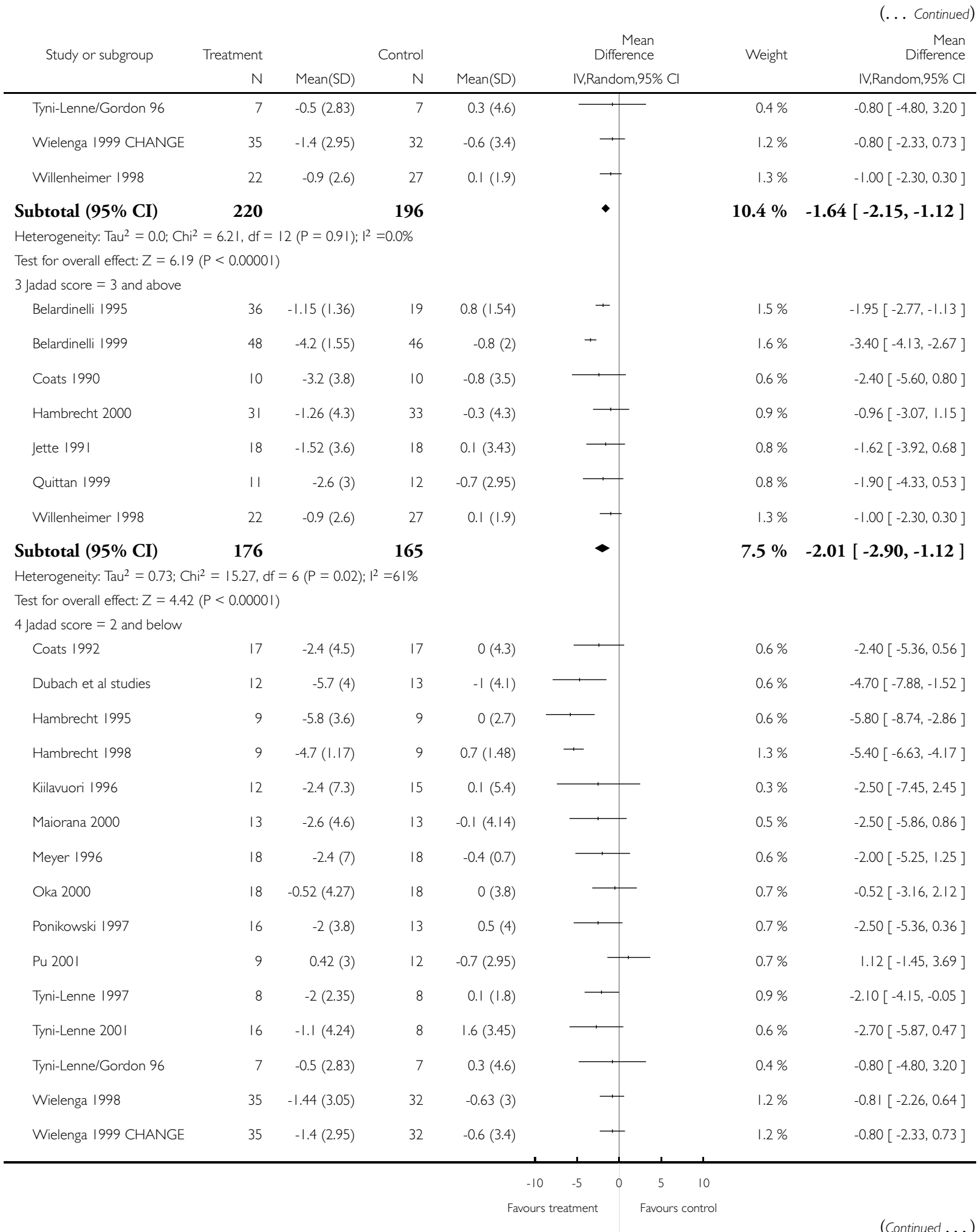

Exercise based rehabilitation for heart failure (Review) 


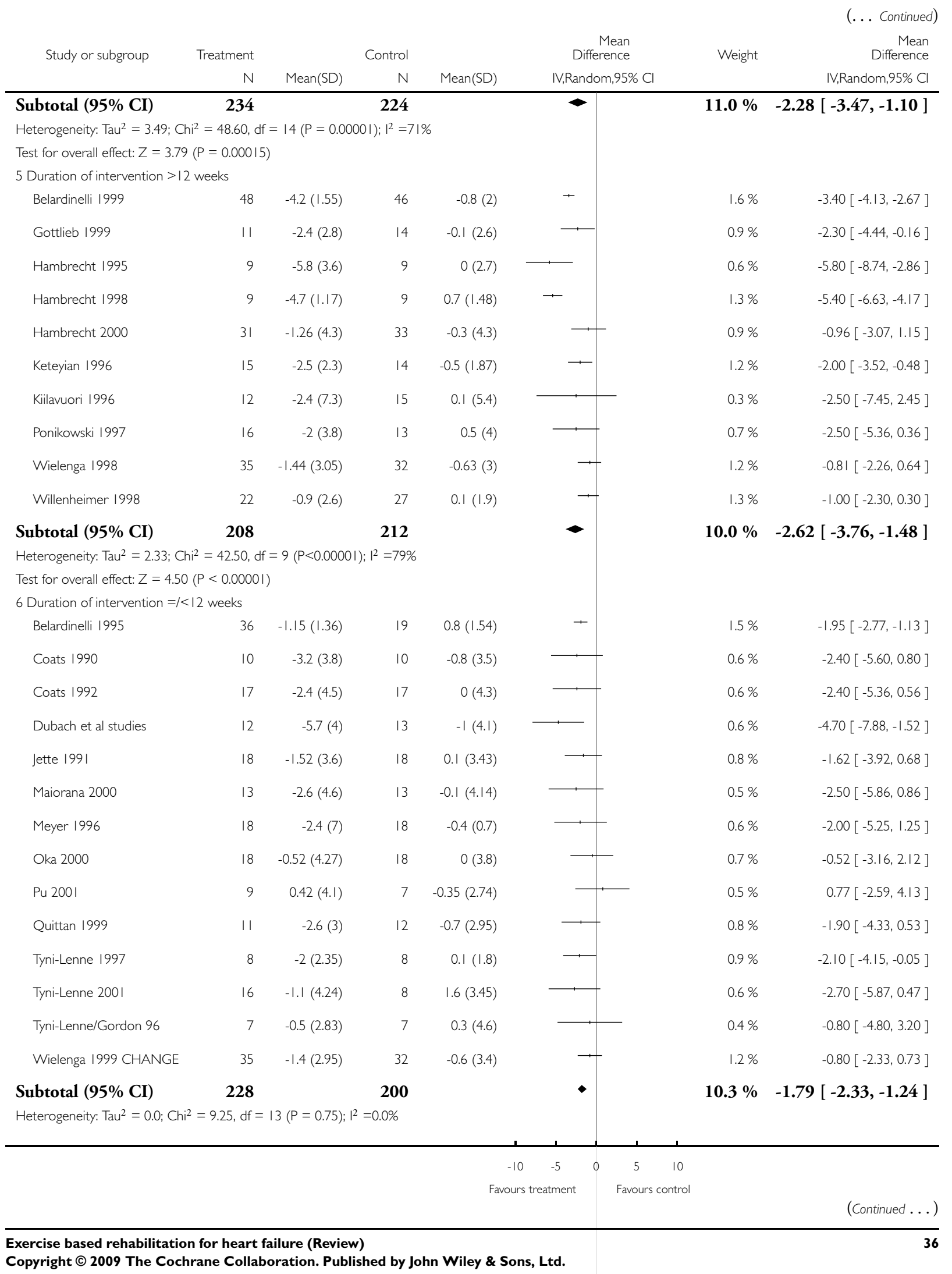




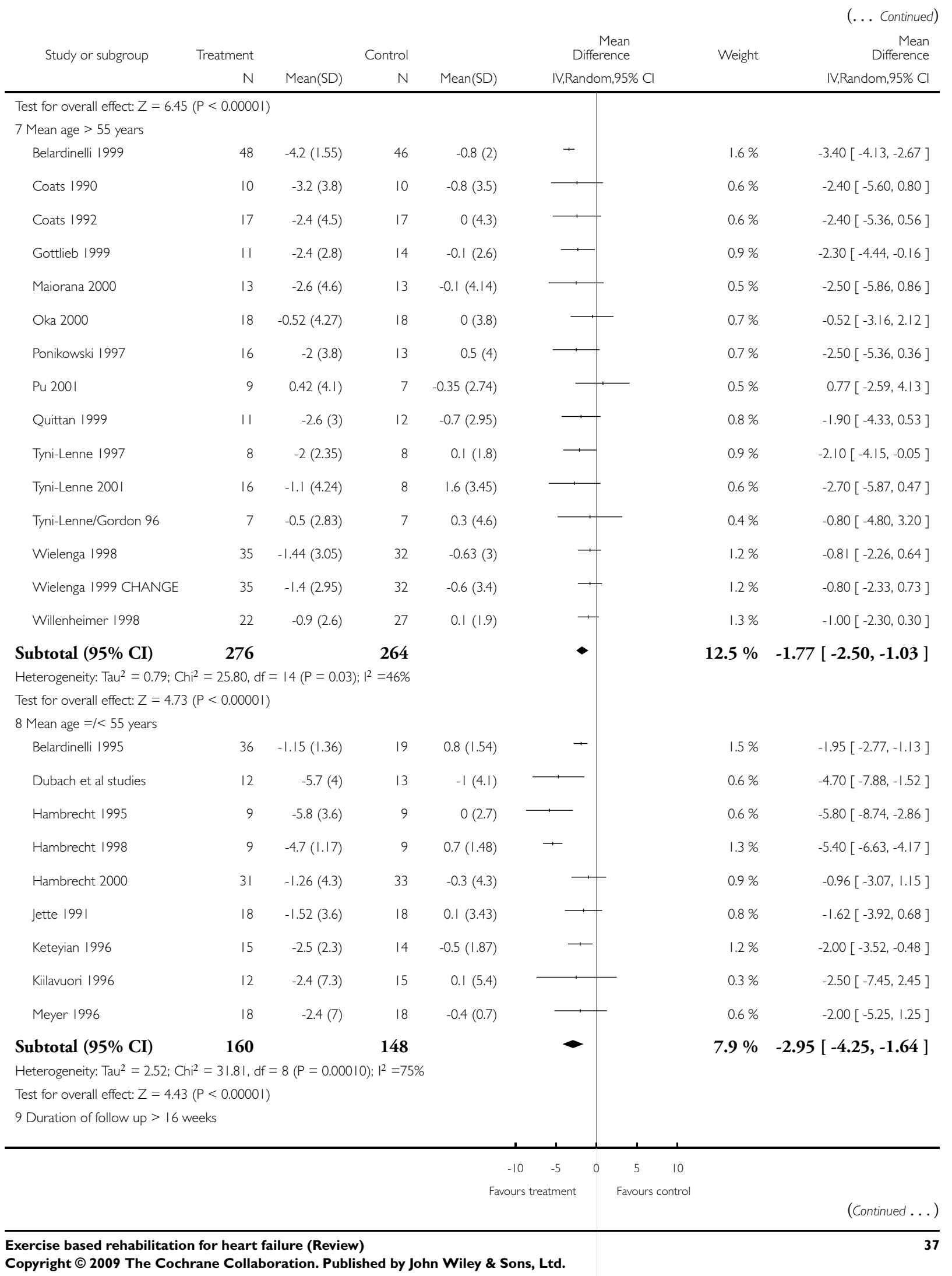




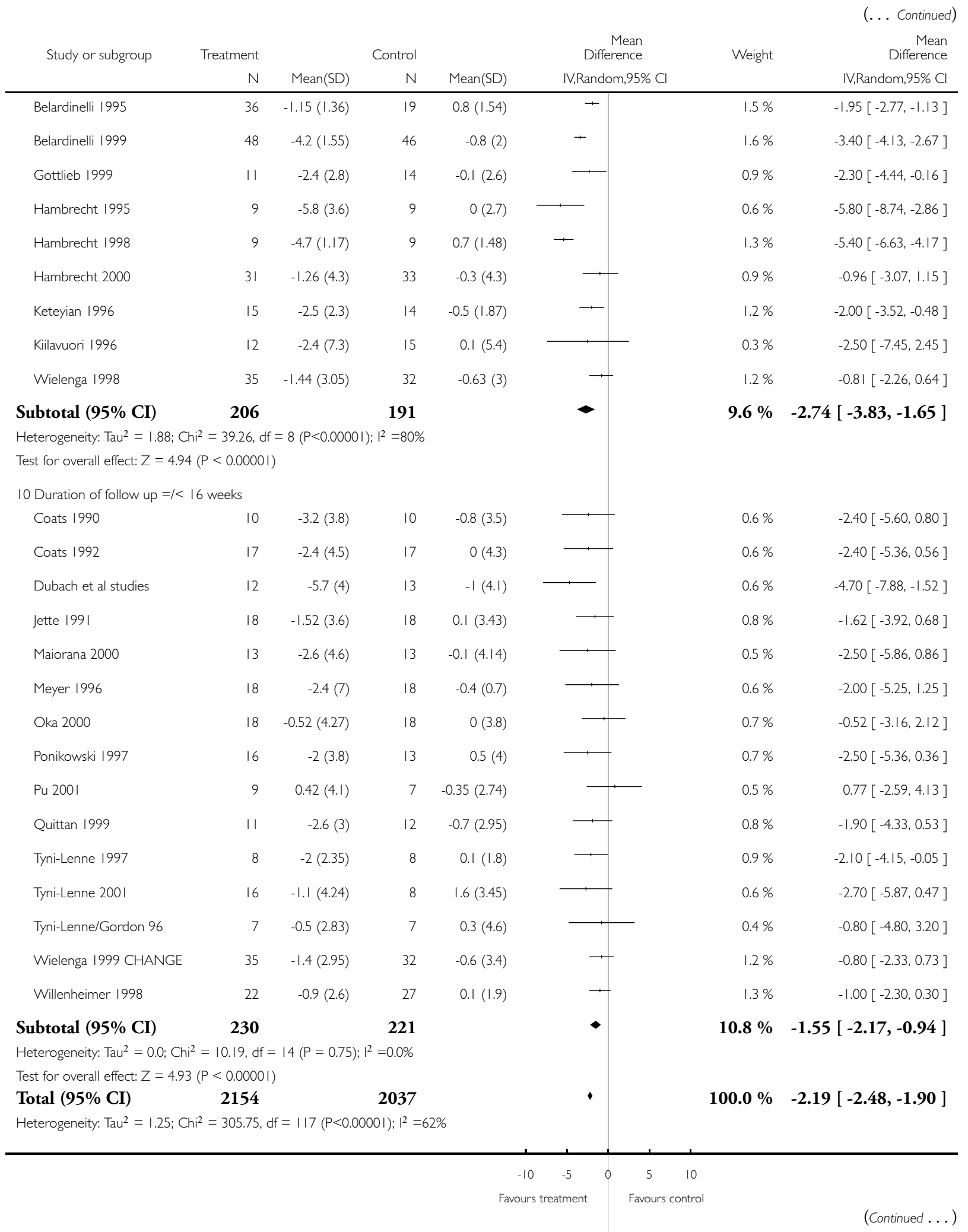

Exercise based rehabilitation for heart failure (Review) 


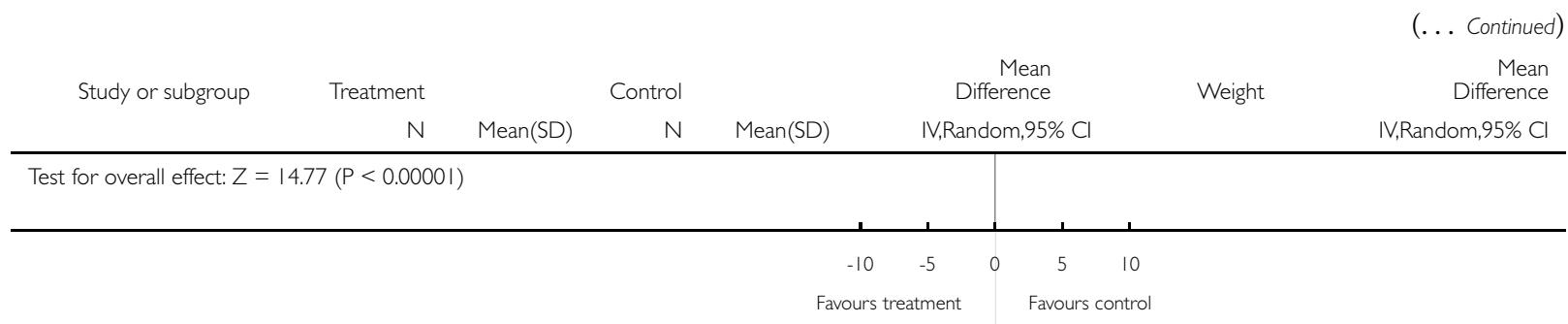

\section{WHAT'S NEW}

Last assessed as up-to-date: 17 May 2004.

\begin{tabular}{l|ll}
\hline Date & Event & Description \\
\hline 8 September 2008 & Amended & Converted to new review format. \\
\hline
\end{tabular}

\section{H I S T O R Y}

Protocol first published: Issue 4, 2001

Review first published: Issue 3, 2004

\begin{tabular}{|c|c|c|}
\hline Date & Event & Description \\
\hline 18 May 2004 & New citation required and conclusions have changed & Substantive amendment \\
\hline
\end{tabular}

\section{CONTRIBUTIONSOFAUTHORS}

All co-reviewers were involved in the design of the review and in providing critical comments about the manuscript. Karen Rees and Rod Taylor independently selected studies for inclusion, extracted data from the source papers and analysed the data. Andrew Coats and Sally Singh provided clinical expertise. Shah Ebrahim acted as the principal advisor. 


\section{DECLARATIONSOF INTEREST}

RT - former chair of BACR Scientific Sub-Committee, written a number of publications in the field of cardiac rehabilitation and currently involved in two UK RCTs of cardiac rehabilitation.

AC - author of 2 of the included trials, and a number of papers in the field of heart failure.

\section{SOURCES OF SUPPORT}

\section{Internal sources}

- Department of Social Medicine, University of Bristol, UK.

- Department of Public Health and Epidemiology, University of Birmingham, UK.

\section{External sources}

- British Heart Foundation, UK.

\section{NOTES}

The Peninsula Technology Assessment Group (PenTAG) at Peninsula Medical School, Exeter, UK and the Cochrane Heart Group have been awarded a 3-year grant from the National Institute for Health Research to update existing Cochrane systematic reviews relevant to public health, primary care and rehabilitation.

This review is scheduled to be updated in the first year of the program. Publication of the updated review is anticipated by issue 2 , 2009 at the latest.

\section{INDEX TERMS}

\section{Medical Subject Headings (MeSH)}

*Exercise Therapy; Cardiac Output, Low [* rehabilitation; therapy]; Chronic Disease; Heart Failure [* rehabilitation; therapy]; Quality of Life; Randomized Controlled Trials as Topic

\section{MeSH check words}

Humans 